Article

\title{
Crop Wild Relatives (CWR) Priority in Italy: Distribution, Ecology, In Situ and Ex Situ Conservation and Expected Actions
}

\author{
Enrico Vito Perrino ${ }^{1, * \mathbb{D}}$ and Robert Philipp Wagensommer ${ }^{2}$ \\ 1 CIHEAM, Mediterranean Agronomic Institute of Bari, 70010 Valenzano, Italy \\ 2 Department of Biology, University of Bari "Aldo Moro", 70125 Bari, Italy; robert.wagensommer@uniba.it \\ * Correspondence: perrino@iamb.it or enricoperrino@yahoo.it
}

check for updates

Citation: Perrino, E.V.;

Wagensommer, R.P. Crop Wild

Relatives (CWR) Priority in Italy:

Distribution, Ecology, In Situ and Ex

Situ Conservation and Expected

Actions. Sustainability 2021, 13, 1682.

https://doi.org/10.3390/su13041682

Academic Editor: José

Manuel Mirás-Avalos

Received: 20 January 2021

Accepted: 1 February 2021

Published: 4 February 2021

Publisher's Note: MDPI stays neutral with regard to jurisdictional claims in published maps and institutional affiliations.

Copyright: (c) 2021 by the authors. Licensee MDPI, Basel, Switzerland. This article is an open access article distributed under the terms and conditions of the Creative Commons Attribution (CC BY) license (https:// creativecommons.org/licenses/by/ $4.0 /)$.

\begin{abstract}
The study presents an updated overview of the 14 non-endemic threatened crop wild relatives (CWR) in Italy: Aegilops biuncialis, Ae. uniaristata, Ae. ventricosa, Asparagus pastorianus, Beta macrocarpa, Brassica insularis, B. montana, Crambe hispanica subsp. hispanica, C. tataria subsp. tataria, Ipomoea sagittata, Lathyrus amphicarpos, L. palustris, Vicia cusnae and V. serinica. Geographical distribution, ecology (with plant communities and habitat 92/43/EEC aspects), genetics (focused on gene pools), property, and in situ and ex situ conservation were analyzed. In addition, with the aim of their protection and valorization, specific actions are recommended.
\end{abstract}

Keywords: gene pool; geographical distribution; threatened species; valorization

\section{Introduction}

Crop wild relatives (CWRs) are wild species closely related to crops and are potential sources of important traits (such as pest or disease resistance), yield improvement and/or stability [1]. It must also be considered that they are a critical component of plant genetic resources for food and agriculture (PGRFA), although they have been neglected for conservation purposes [1], and in situ and ex situ conservation approaches should be deployed to ensure their availability for use [2].

In monetary terms, the CWRs have contributed significantly to the agricultural and horticultural industries, and to the world economy [3,4]. Pimentel et al. [5] estimated that wild relatives contribute approximately USD 20 billion toward increased crop yields per year in the United States, and USD 115 billion worldwide. Phillips and Meilleur [6] noted that losses of rare wild plants represent a substantial economic loss to agriculture, estimating that the endangered food crop relatives have a worth of about USD 10 billion annually in wholesale farm values. Although these studies show significant divergence, they highlight the major global economic value of CWR diversity to humanity.

Following the definition of Maxted et al. [7], the CWRs are taxa belonging to the same genus as the cultivated species. With this approach, about $80 \%$ of the European and Mediterranean flora species are CWRs and important from a socioeconomic point of view [8]. However, a genetic rather than a taxonomic approach suggests that only those species able to interbreed with cultivated species in relation to their "gene pool" should be considered CWRs. According to Harlan and de Wet [9], the gene pool represents a reservoir of diversity that can be tapped into by organisms to adapt to a changing environment, and breeders for crop improvement. Wild relatives of a given crop are thought to be in the same gene pool, and even when they appear to be taxonomically different, they can exchange genes with their related cultivated taxon. Unfortunately, not all wild relatives are equally ready to do this. For this reason, CWRs have been classified into three groups (GP1, GP2, GP3) based on the ability to exchange genes with the cultivated species to which they are naturally related [9]. The primary gene pool (GP1) includes species that can be directly crossed with the cultivated species to produce fertile breeds. For example, it is easier for Beta macrocarpa Guss. (GP1) to interbreed with cultivated chard (Beta vulgaris L.) because 
they have a very good genetic affinity, as opposed to other species that are less closely related, and which belong to more distant gene pools (GP2 or GP3).

The aim of the work was to assess the state of the art of the 14 non-endemic CWR priority in Italy, focusing on their distribution, ecology, natural habitats [10,11], and in situ and ex situ conservation [12-14], in order to draw up the planned actions for their conservation and enhancement.

\section{Materials and Methods}

The study was planned starting with 43 Italian threatened CWRs $[15,16]$, according to the taxon group concept of CWRs [7] and not regarding the gene pool concept [9], from which the 29 taxa endemic to Italy were excluded and will be treated in a separate work. Thus, the following 14 taxa were investigated: Aegilops biuncialis Vis., Ae. uniaristata Vis., Ae. ventricosa Tausch, Asparagus pastorianus Webb \& Berthel, Beta macrocarpa Guss., Brassica insularis Moris, B. montana Pourr., Crambe hispanica L. subsp. hispanica, C. tataria Sebeók subsp. tataria, Ipomoea sagittata Poir., Lathyrus amphicarpos L., L. palustris L., Vicia cusnae Foggi \& Ricceri and V. serinica R. Uechtr. et Huter.

The nomenclature of the taxa follows "An updated checklist of the Vascular flora native to Italy" [17] (Bartolucci et al. 2018), while the syntaxonomic references were conceived by several contributions [18,19] (Biondi, Blasi, 2015, Rivas-Martínez et al. 2004).

The taxa at risk were those reported in Annex I of the International Treaty on Plant Genetic Resources for Food and Agriculture (ITPGRFA) [15], those mentioned by the Italian Institute of Statistics (ISTAT) for cultivated areas and yield between 2007 and 2012 [20], the policy species threatened and near threatened, and the taxa included in Red Lists, at both Italian and European level [21-32], in the Bern Convention [33], and in the Annexes to the 92/43/EEC Directive [34] (Table 1).

Table 1. Prioritized list of 14 (non-endemic) taxon group crop wild relatives and reasons for threat, adapted and updated from Landucci et al. [35], Magrini et al. [16] and Perrino and Perrino [1].

\begin{tabular}{|c|c|c|c|c|c|c|c|c|c|c|c|c|}
\hline Taxa & IT & IS & 1 & $\ddagger 2$ & $\ddagger 3$ & $\ddagger 4$ & 5 & 6 & 7 & 8 & 9 & 10 \\
\hline Aegilops biuncialis & $x$ & $x$ & LC & $\mathrm{CR}$ & & & & & & $\mathrm{VU}^{1}$ & & \\
\hline $\begin{array}{l}\text { Aegilops } \\
\text { uniaristata }\end{array}$ & $x$ & $x$ & $\mathrm{LC}$ & EN & & DD & $\mathrm{V}$ & VU & & $\mathrm{VU}^{2}$ & & \\
\hline Aegilops ventricosa & $x$ & $x$ & $\mathrm{LC}$ & & & & & & & $\mathrm{VU}^{3}$ & & \\
\hline $\begin{array}{l}\text { Asparagus } \\
\text { pastorianus }\end{array}$ & $x$ & $x$ & VU & VU & VU & & & & $\mathrm{NT}^{2}$ & & & \\
\hline Beta macrocarpa & $x$ & $x$ & EN & & & & & & & & & \\
\hline Brassica insularis & $x$ & $x$ & NT & & EN & & & NT & $\mathrm{NT}^{1}$ & $\mathrm{NT}^{4}$ & $x$ & $x$ \\
\hline Brassica montana & $x$ & $x$ & $\mathrm{LC}$ & & & & & VU & $\mathrm{VU}^{2}$ & & & \\
\hline $\begin{array}{l}\text { Crambe hispanica } \\
\text { subsp. hispanica }\end{array}$ & $x$ & & $\mathrm{LC}$ & & EW & & & & & $\mathrm{VU}^{5}$ & & \\
\hline $\begin{array}{l}\text { Crambe tataria } \\
\text { subsp. tataria }\end{array}$ & $x$ & & LC & VU & & & $\mathrm{V}$ & NT & $\mathrm{NT}^{1}$ & & $x$ & \\
\hline Ipomoea sagittata & $x$ & $x$ & VU & EN & EN & & $\mathrm{E}$ & & & & & \\
\hline $\begin{array}{l}\text { Lathyrus } \\
\text { amphicarpos }\end{array}$ & $x$ & $x$ & NT & $\mathrm{LR}$ & LR & & $\mathrm{R}$ & & & & & \\
\hline Lathyrus palustris & $x$ & $x$ & & & & & & EN & $\mathrm{EN}^{2}$ & & & \\
\hline Vicia cusnae & $\mathrm{x}$ & $x$ & & LR & & & $\mathrm{R}$ & VU & & $\mathrm{VU}^{6}$ & & \\
\hline Vicia serinica & $x$ & $x$ & & LR & & & $\mathrm{R}$ & & $\mathrm{EN}^{2}$ & & & \\
\hline
\end{tabular}

IT (ITPGRFA): taxa included in Annex I of the International Treaty on Plant Genetic Resources for Food and Agriculture [15]. IS (ISTAT): taxa mentioned by the Italian Institute of Statistics (ISTAT) for cultivated areas and yield in the last 5 years before 2012 [20]. 1 (Bilz et al. [24]; European Red List): EN, Endangered; LC, Least Concern; NT, Near Threatened; VU, Vulnerable. $\ddagger$ (Conti et al. [22]) 2, Italy; 3, Sicily; 4, Sardinia: EW, Extinct in the wild; CR, Critically Endangered; EN, Endangered; VU, Vulnerable; LR, Lower Risk; DD, Data deficient. 5 (Conti et al. [21]; National Red List): E, Endangered; V, Vulnerable; R, Rare. 6 (Rossi et al. [25]; Italian Red List of Policy Species and other threatened species): EN, Endangered; VU, Vulnerable; NT, Near Threatened. 7 (RED LIST OF THREATENED VASCULAR PLANTS IN ITALY: taxa included in ${ }^{1}$ Rossi et al. [26] and in ${ }^{2}$ Orsenigo et al. [32]): EN, Endangered; VU, Vulnerable, NT, Near Threatened. 8 (OTHER IUCN CARDS: taxa included in "Red List of Italian Vascular and Cryptogamic Flora cards" published since 2013 on Informatore Botanico Italiano become Italian Botanist, ${ }^{1}$ Perrino and Wagensommer [28], ${ }^{2}$ Perrino and Wagensommer [27], ${ }^{3}$ Perrino and Wagensommer [29], ${ }^{4}$ Santo et al. [31], ${ }^{5}$ Perrino et al. [30], ${ }^{6}$ Foggi et al. [23]): VU, Vulnerable; NT, Near Threatened. 9 (EUROPEAN COMMISSION): Annex II of the Directive 92/43/EEC [34]. 10 (BERN CONVENTION): Appendix I [33]. 
For each of the 14 non-endemic wild relatives, three levels of attention were considered regarding ex situ conservation: (1) High Priority (HP) for taxa present in the Italian RIBES (Rete Italiana delle Banche del Germoplasma) seed banks with zero accessions; (2) Normal Priority (NP) for taxa present with fewer than five accessions (from 1 to 4); and (3) Zero Priority (ZP) for those species present with five or more accessions (from 5 to 140). Furthermore, for the same taxa, one level of attention for the in situ conservation (A) was considered, which included the native taxa related to a crop of worldwide and national importance for food and agriculture, which were included in (at least) the National and in the European Red Lists, and in the International Conventions and that need specific monitoring/protection measures (Table 1). No taxa belonging to the other two levels of attention for the in situ conservation were identified: (1) level (B), concerning the native taxa related to important crops, which on the basis of current knowledge, have no need of any immediate specific protection or monitoring measures; (2) level (C) that includes the native taxa related to important crops, neither endemic nor subendemic to Italy, which, on the basis of current knowledge, have no need of any immediate specific protection or monitoring measures $[1,35]$. For a better evaluation of in situ and ex situ conservation, vegetation and 92/43/EEC habitat data have been included (Table 2).

Finally, the 14 non-endemic wild relatives were evaluated considering their gene pools (GP1, GP2 and GP3), according to the concept of Harlan and de Wet [9], by consulting the checklist www.cwrdiversity.org/checklist/ (accessed on 2 November 2020) and Vincent et al. [36], and checking their in situ and ex situ conservation priorities (Table 3).

Table 2. Prioritized list of 14 taxon group crop wild relatives (non-endemic), their status of ex situ and in situ conservation, and relationships with plant communities and/or habitat 92/43 EEC.

\begin{tabular}{|c|c|c|c|c|c|}
\hline \multirow{2}{*}{ Taxa } & \multicolumn{3}{|c|}{$\begin{array}{c}\text { Ex Situ Priority } \\
\text { Conservation }\end{array}$} & \multirow{2}{*}{$\begin{array}{c}\begin{array}{c}\text { In Situ Priority } \\
\text { Conservation }\end{array} \\
\text { A }\end{array}$} & \multirow{2}{*}{ Syntaxon/Habitat (Code) } \\
\hline & HP & NP & $\mathbf{Z P}$ & & \\
\hline Aegilops biuncialis & & $X$ & & $X$ & $\left(6220^{*}\right)$ \\
\hline Aegilops uniaristata & & $x$ & & $x$ & $\left(6220^{*}\right)$ \\
\hline Aegilops ventricosa & & $X$ & & $X$ & $\left(6220^{*}\right)$ \\
\hline Asparagus pastorianus & $x$ & & & $X$ & Asparago pastoriani-Chamaeropetum humilis \\
\hline Beta macrocarpa & $X$ & & & $X$ & $?$ \\
\hline Brassica insularis & & & $X$ & $X$ & $?$ \\
\hline Brassica montana & & & $X$ & $X$ & Reichardio maritimae-Brassicetum robertianae \\
\hline Crambe hispanica subsp. hispanica & & & $X$ & $X$ & Crambetum hispanicae \\
\hline Crambe tataria subsp. tataria & & $x$ & & $X$ & Centaureo-Globularietum cordifoliae (62A0) \\
\hline Ipomoea sagittata & $X$ & & & $X$ & Calystegion sepium (6430) \\
\hline Lathyrus amphicarpos & $x$ & & & $x$ & ? \\
\hline Lathyrus palustris & $X$ & & & $X$ & Molinio-Arrhenatheretea $(6410,6420)$ \\
\hline Vicia cusnae & $x$ & & & $x$ & Thlaspion rotundifolii (8210) \\
\hline Vicia serinica & $X$ & & & $X$ & Sideridenion italicae $\left(6210^{*}\right)$ \\
\hline TOTAL & 7 & 4 & 3 & 14 & \\
\hline
\end{tabular}

Ex situ priority conservation. HP: taxa with high priority (zero accessions), NP: taxa with normal priority (1-4 accessions), ZP: taxa with no priority (5-140 accessions). Adapted and updated from Magrini et al. [16]. In situ priority conservation. A: native taxa related to a crop of worldwide and national importance for food and agriculture, which are included as Threatened (EW, CR, EN, VU) or Near Threatened in (at least) one of the following sources: IUCN (European Red List) [24], Regional Red List (national catalogue and catalogue for Sicily and Sardinia) [22], National Red List [21,23,25-31,37]. These taxa need specific protection and/or monitoring measures. Vegetation type and/or Habitat 92/43 EEC (Italy). Code habitat [38]. Vegetation type (see reference in the text when discussing the relative species). 
Table 3. Crop wild relatives (8 out of 14) belonging to at least one gene pool and their conservation prioritization updated from Landucci et al. [35] and Perrino and Perrino [1].

\begin{tabular}{|c|c|c|c|c|c|c|c|}
\hline \multirow{2}{*}{ Taxa } & \multicolumn{3}{|c|}{ Gene Pools (GP) } & \multicolumn{3}{|c|}{ Ex Situ Priority Conservation } & \multirow{2}{*}{$\begin{array}{c}\begin{array}{c}\text { In Situ Priority } \\
\text { Conservation }\end{array} \\
\text { A }\end{array}$} \\
\hline & GP1 & GP2 & GP3 & HP & NP & ZP & \\
\hline Aegilops biuncialis & & $x$ & $x$ & & $x$ & & $x$ \\
\hline Aegilops uniaristata & & $X$ & $X$ & & $x$ & & $X$ \\
\hline Aegilops ventricosa & & $x$ & $x$ & & $x$ & & $x$ \\
\hline Beta macrocarpa & $x$ & & & $x$ & & & $x$ \\
\hline Brassica insularis & & $x$ & $x$ & & & $x$ & $X$ \\
\hline Brassica montana & & $x$ & $x$ & & & $x$ & $x$ \\
\hline $\begin{array}{l}\text { Crambe hispanica } \\
\text { subsp. hispanica }\end{array}$ & $X$ & & & & & $x$ & $X$ \\
\hline $\begin{array}{c}\text { Lathyrus } \\
\text { amphicarpos }\end{array}$ & & $x$ & & $x$ & & & $x$ \\
\hline TOTAL & 2 & 6 & 5 & 2 & 3 & 3 & 8 \\
\hline
\end{tabular}

Gene Pools (GP): taxa with a certain use in plant breeding belonging to the primary (GP1), secondary (GP2) and tertiary GP (GP3). Ex situ priority conservation. HP: taxa with high priority, NP: taxa with normal priority, ZP: taxa with zero priority. Adapted and updated from Magrini et al. [16]. In situ priority conservation. A: includes native taxa related to a crop of worldwide and national importance for food and agriculture, which are included as Threatened (EW, CR, EN, VU) or Near Threatened in (at least) one of the following sources: IUCN (European Red List) [24], Regional Red List (national catalogue and catalogue of Sicily and of Sardinia) [22], National Red List $[21,25,26,29,32,37]$. These taxa need specific protection and/or monitoring measures.

The results are shown in alphabetical order by genus and species and are discussed individually with the evaluation of the following aspects: geographical distribution, reasons of threat and priorities for conservation (both ex situ and in situ), ecology, vegetation types (only those recognized from a phytosociological point of view) and/or habitat 92/43/EEC, properties, and a management indicator (called "expected actions").

\section{Results}

According to the taxon group concept, the 14 non-endemic CWR priorities in Italy belong to the Brassicaceae and Fabaceae families, each with four species, followed by Poaceae with three species, and Asparagaceae, Chenopodiaceae and Convolvulaceae, each represented by only one species. The most represented genus is Aegilops L. with three species, followed by Brassica L., Crambe Vosmaer, Lathyrus Schinzand and Vicia L., each with two species, and finally the genera Asparagus L., Beta L. and Ipomoea L., with only one species (Table 1).

\subsection{Ex Situ and In Situ Conservation}

\subsubsection{Taxon Group CWR with High Priority (A) of Conservation}

Accordingly, we crossed the data of the 760 species selected for their need of in situ [35] and for their need of ex situ [16] conservation, with those of the 14 selected species, with the aim to compare the situation of the latter for their in situ and ex situ conservation. The results showed that, for in situ conservation, all species (14 out of the 14) had the highest priority (A), while for ex situ conservation, seven species had the highest priority (HP), four normal priority (NP), and three zero priority (ZP) (Table 2).

\subsubsection{Relationship between In Situ and Ex Situ Conservation}

Globally, all species (14 out of 14) had a highest priority for in situ (A) conservation, but only half of the total (7 out of 14), Asparagus pastorianus, Beta macrocarpa, Ipomoea sagittata, Lathyrus amphicarpos, L. palustris, Vicia cusnae, and V. serinica, were in the worst situation, because they also had the highest priority for ex situ (HP) conservation. For the remaining species, the situation could be considered less hard, because high priority for in situ (A) was balanced by low (NP) or zero (ZP) priority for ex situ (only three taxa with 
zero priority). In conclusion, all species had high in situ priority (A) and need monitoring and updating, and should be considered at risk (Table 2).

\subsubsection{The 14 Taxon Group CWRs in the Light of the Gene Pool Concept}

Plant breeders concentrate on wild relatives that may cross easily with crops; therefore, we have checked which ones of the 14 taxon group wild species belong to the three gene pools, foreseen by the Harlan and de Wet [9] concept. The results (Table 3) show that only 8 species out of the 14 belonged to one or two gene pools. In particular, two species, Beta macrocarpa and Crambe hispanica subsp. hispanica, shared only the primary gene pool (GP1); five species, Aegilops biuncialis, Ae. uniaristata, Ae. ventricosa, Brassica insularis (Policy species), and B. montana, shared the secondary and tertiary gene pools (GP2 and GP3); and one species, Lathyrus amphicarpos, belonged only to the secondary gene pool (GP2), and not GP3, as indicated by www.cwrdiversity.org/checklist/ (accessed on 20 November 2020). In conclusion, two species belonged only to GP1, one only to GP2, five shared GP2 and GP3, while for the other six taxa, at the moment, to the best of our knowledge, there is no information.

\section{Discussion}

\subsection{Aegilops biuncialis Vis., Aegilops uniaristata Vis. and Aegilops ventricosa Tausch}

The genus Aegilops L. has been intensively studied due to its close relationship with cultivated wheats, and their vast genetic diversity represents a rich source of alleles of agronomic interest, which could be used to widen the wheat gene pool and improve tolerance to diseases, pests, drought, cold and other environmental stresses [39], and for improving micro-nutrient content (such as Fe and $\mathrm{Zn}$ ) in wheat grains. About the last point, it should be noted that $\mathrm{Zn}$ deficiency affects $17.3 \%$ of the world population, mostly in Asia and Africa, leading to the death of over 400,000 children every year [40-42]. Wheat rich in micronutrients, i.e., bio-fortified wheat, can improve the lives of these people. It is difficult to find germplasm with high $\mathrm{Zn}$ and Fe content in the wheat gene pool [43], although some Ae. show three- to four-fold higher Zn and Fe grain content, such as Ae. ventricosa (genome DN) [44].

In Europe, wild wheat relatives of the Triticum-Aegilops complex grow in sympatry with cultivated bread wheat (Triticum aestivum L.), and spontaneous hybridization is known for most of the tetraploid Ae. species. The probability of gene transfer and gene retention in hybrid progenies is, however, higher when a gene is located on a shared genome, particularly on the D genome shared with Ae. cylindrica and Ae. ventricosa. Through optimized experimentation, some studies have shown to support the hybridization (experimental soil layout, flowering synchrony) that the cross-pollination between the cultivated wheat and its relatives occur at a significant level as for Ae. biuncialis [45].

The chromosome number is $4 \mathrm{n}=28$ in Ae. biuncialis, $2 \mathrm{n}=14$ in Ae. uniaristata, and $4 \mathrm{n}=28$ in Ae. ventricosa $[46,47]$.

The species belonging to this genus are mainly distributed in Southwest and Central Asia and throughout the Mediterranean Basin [48,49]. In Italy, their geographical distribution, ecology, vulnerability has been updated [50]. Among the priority CWRs, it is the most represented genus, with three species (Ae. biuncalis (genome UM), Ae. uniaristata (genome $\mathrm{N}$ ) and Ae. ventricosa (genome DN)) all listed as threatened in the red lists (Table 1), with high in situ priority (A), and normal ex situ priority (NP) (Table 2) and secondary and tertiary gene pools (GP2 and GP3) (Table 3).

The flowering time of Ae. in Italy is from April to June, depending on the species and its eco-geographical location [50], and partially meets the flowering of the cultivated wheat that starts in May and ends in June [51], a phenological condition that would suggest in situ crossbreeding experimentation.

The three aforementioned Ae. species grow in peculiar annual meadows of Brachypodietalia distachyi Rivas-Martínez 1978 (syn.: Trachynietalia distachyae Rivas-Martínez 1978) 
order (subtype 3 of priority habitat $6220^{*}$ ) [50,52], but a specific classification framework from a phytosociological point of view is lacking.

\section{Expected Actions}

- In situ and ex situ conservation to prevent the risk of extinction by increasing the number of individuals of existing wild populations.

- In situ translocation to the edge of fields of cultivated ancestral wheat to verify and update the hybridization capacity, thanks to the comparable flowering periods.

- Starting cultivation in cooperation with local farmers, especially of Ae. ventricosa that, unlike cultivated wheat varieties, has a higher quantity of microelements such as $\mathrm{Fe}$ and $\mathrm{Zn}$. Then, verify the prospect of production and marketing of its flour and/or pasta as a natural alternative to conventional medicine, and helpful for people with $\mathrm{Fe}$ and $\mathrm{Zn}$ deficiencies.

- Study plant communities of annual meadows to define their phytosociological framework.

\subsection{Asparagus pastorianus Webb \& Berthel}

Several wild species of the genus Asparagus L. in the Italian Peninsula have long been the object of harvesting for food consumption, and in the case of A. officinalis L., also of ancient domestication and cultivation. Since the Middle Ages, the cultivated and wild species of this genus has always had an important place in the gastronomic culture. The young shoots of $A$. pastorianus are eaten in Morocco (vernacular name: sekoum), the stems and roots are used in popular medicine as aphrodisiacs $[53,54]$ in the Canary Islands (vernacular names: "esparraguera de espinas" or "espina blanca") and to produce smoke, prepare infusion, decoction with white wine, as insect repellent, and diuretic slimming. The bioactive phytochemicals are glycosides and sapogenins [55].

A. pastorianus is a perennial shrub that grows in the garrigues near the sea, and has a south-western Mediterranean-Macaronesian distribution. In Italy, the species grows only in a restricted area of the Sicilian Region [17]. On the southern coast of Sicily, between Selinunte and the mouth of the Verdura River, on Pleistocene deposits consisting of a succession of calcarenites and sandy clays, grows a peculiar low shrubby plant community association characterized by $A$. pastorianus, described as Asparago pastoriani-Chamaeropetum humilis Raimondo \& Bazan 2008 [56], included in the alliance Oleo-Ceratonion Br.-Bl. ex Guinochet \& Drouineau 1944 em. Rivas-Martínez 1975.

The dispersion of seeds in the Canary Islands (Lanzarote, Fuerteventura, Gran Canaria, Tenerife, La Gomera) occurs through small mammals (e.g., squirrels) [57] and birds (e.g., shrikes and kestrels) [58], although there are no available data from the Sicilian population.

The chromosome number is $2 \mathrm{n}=40$ [59] (material from Santa Lucía, Gran Canaria, cultivated in the Botanical Garden in Oslo). Although the gene pool is unknown, among the conservation priorities, $A$. pastorianus is one of the most important for conservation interest because it is listed in the red list with VU category in Europe [24] and NT category in Italy [32] (Table 1), resulting in a high in situ (A) and ex situ (HP) priority (Table 2).

\section{Expected Actions}

- Monitoring of the few known sites of coastal area in southern Sicily, well preserved and for which in situ conservation actions would be appropriate, because of the following potential threats: (a) policy developments that aim at tourist exploitation [56]; and (b) potential negative effect of mammals, especially rodents and lagomorphs on seed germination, as already observed in the Canary Islands [60].

- Targeted actions for the collection of germplasm to ex situ conservation because the species has zero accessions in the RIBES seed banks.

- $\quad$ Research activities to verify the gene pool through crossing with other species of the same genus and any differences with the populations of the Canary Islands and Morocco.

- Verify the seed dispersal system in Sicily, as was done in the Canary Islands. 
- Evaluate the enhancement of the Sicily populations for the production of their use for medicinal purposes.

\subsection{Beta macrocarpa Guss}

The genus Beta L. is divided into two sections: Beta and Corollinae [61]. The section Beta includes five taxa, B. vulgaris L. subsp. maritima (L.) Arcang. (the sea beet), which is considered as the wild ancestor of all cultivated beets, the different forms of cultivated beets (B. vulgaris L. subsp. vulgaris), discovered wild in Calabria [62], B. macrocarpa, which is an annual self-compatible plant thought to reproduce predominantly by autogamy, $B$. patula Aiton, which is endemic to two small islets of the Madeira Archipelago [63], and finally B. vulgaris L. subsp. adanensis (Pamukç.) Ford-Lloyd \& J.T. Williams, that grows in some Eastern Mediterranean areas of Greece and Turkey $[61,64,65]$. Therefore, in the western Mediterranean area, only two species of the section Beta can be found in coastal and inland ruderal habitats: B. vulgaris subsp. maritima and B. macrocarpa [66]. B. macrocarpa is located in inland or coastal habitats in western and eastern Mediterranean areas [67] and in Italy it grows in uncultivated clayey soils [68] in Campania, Basilicata and Sicily, while its occurrence is doubtful in Sardinia and Trentino Alto Adige [17].

The chromosome number of $B$. macrocarpa is $2 \mathrm{n}=36$ (from accessions of the Canary Islands) [69]. B. macrocarpa is closely related to B. vulgaris subsp. maritima by genetic structure. In particular, B. macrocarpa has a genotypic structure and a high level of genetic differentiation indicative for selfing (an extreme degree of inbreeding) [66]. In fact, the two species can spontaneously hybridize [69-71], sharing the primary gene pool (GP1) (Table 3).

This species is listed in the European red list [24] with EN category (Table 1), shows high in situ priority (A) and high ex situ priority (HP) (Table 2), and primary gene pool (GP1) (Table 3). It is worth noting that the wild taxa of section Beta, except B. vulgaris subsp. maritima, are all listed in IUCN Red List, as VU (B. vulgaris subsp. adanensis) [72], EN (B. macrocarpa) [73] and CR (B. patula) [74]. For threatened therophytes, such as B. macrocarpa, it is important to consider that natural phenomena can cause considerable fluctuations in the number of individuals, and that therefore repeated counts in subsequent years are necessary for a correct estimate of the population size [75].

A specific study on herbaceous vegetation useful for animals on wetland environments in Tunisia showed a high concentration of minerals in B. macrocarpa, in particular the highest ones compared to all the other herbaceous species, locally sampled, on $\mathrm{K}\left(15.4 \mathrm{~g} \mathrm{~kg}^{-1} \mathrm{dry}\right.$ matter), Ca (31.2 $\mathrm{g} \mathrm{kg}^{-1}$ dry matter), $\mathrm{Mg}\left(15.1 \mathrm{~g} \mathrm{~kg}^{-1}\right.$ dry matter) and although high on average, the lowest $\mathrm{NaCl}\left(54.3 \mathrm{~g} \mathrm{~kg}^{-1}\right.$ dry matter) content among the Chenopodiaceae family, in addition to a high concentration value of phenols $\left(30.1 \mathrm{~g} \mathrm{~kg}^{-1}\right.$ dry matter) and oxalate (64.6 $\mathrm{g} \mathrm{kg}^{-1}$ dry matter) [76].

\section{Expected Actions}

- Cultivation, in cooperation with local farmers and both plant and animal breeders, to test the commercial product, thanks to the high contents of minerals, important for food and feed.

- Monitoring of populations in known areas and field surveys to find new sites.

- Targeted actions for the collection of germplasm to ex situ conservation, because there are no accessions in the RIBES seed banks.

- In situ and ex situ crossing test with Beta vulgaris subsp. maritima, due to the sharing of GP1.

- Phytosociological studies in regions where it grows for vegetation, habitat, and ecological evaluation.

\subsection{Brassica insularis Moris (Policy Species), Brassica montana Pourr}

Wild taxa in B. oleracea L. play an important role to improve cultivated crops, but the genomic relationships between wild and cultivated forms have not been well clarified [77]. $B$. insularis and B. montana belong to B. sect. Brassica, which encloses the taxa with the same 
C genome $(n=9)$ of B. oleracea crops [78-80], and the crossing experiments have confirmed that they are closely related [81].

B. insularis is an endemic Mediterranean member of the B. oleracea group which occurs only in France (Corsica), Italy (Sardinia and Pantelleria), Tunisia (La Galite, Zembra and Zembretta) and Algeria (Kabylie) [31,82], while B. montana is widespread along the coasts of the northern Mediterranean Sea, from north-eastern Spain to south-western Italy [83]. In Italy, B. insularis grows only in two islands (Sicily and Sardinia), and its occurrence is doubtful in Tuscany, while B. montana has a fragmented distribution (Liguria (very common along the coast), Emilia Romagna, Tuscany, Marche, Latium, Campania, Basilicata and Calabria) [17], probably due to its relict origin [84].

Both taxa are listed in red lists (Table 1), with high in situ priority (A), and zero ex situ priority (ZP) (Table 2) due to the 27 accessions present in the seed-banks of Sardinia and Perugia [16], and secondary and tertiary gene pools (GP2, GP3) (Table 3). B. insularis is also listed in Annex II of the Habitat Directive 92/43/EEC [34] and under Appendix I of the Bern Convention [33].

B. insularis is a perennial rupestrian, xerophilous species that grows under the influence of wet marine flows with high soil salinity and marine aerosols, while it is less frequent in inland areas, on slopes, cliffs, and vertical walls, at altitudes from 0 to 1200 $\mathrm{m}$ a.s.l. [31,85], with a flowering period that extends from March to May, and with only a small proportion of individuals flowering in any given month [86].

B. montana grows in habitats influenced by human activities, for instance quarries, roadsides and building grounds [87], and the flowering period is from March to April. On Monte Conero (Marche), B. montana is common in two types of plant communities [84]: (a) the Reichardio maritimae-Brassicetum robertianae Biondi 1982 in rocky crevices of lightly elevated calcareous walls, reached directly by marine aerosol and occasionally by waves; and (b) the B. montana and Matthiola incana (L.) W. T. Aiton community in the most elevated sectors of rocky walls reached by winds with a low salt concentration.

Several studies testify that wild forms can be considered as potential resources to improve the current $B$. oleracea crops, especially when some favorable traits have been identified in wild types of B. oleracea such as resistance against Sclerotinia sclerotiorum [88], blackleg (Peronospora parasitica) [89,90], cabbage white fly (Aleyrodes proletella) [91], and cabbage root fly (Delia radicum) [92]. B. insularis showed seed sinigrin content, with unusual glucosinolate patterns, low progoitrin and high gluconasturtiin levels, and benzyl glucosinolates traces [93], while B. montana showed a high seed glucosinolate content that could be used for increasing the total content of specific glucosinolate profiles for improving biocidal and anticarcinogenic activity in cultivated Brassica [94].

Expected Actions

- All Italian taxa of genus Brassica may be used as genetic resources, with potential host valuable traits that could be transferred to the respective cultivated crops (cabbage, cauliflower, broccoli, etc.) [83], starting from the places with greater ecological affinities and closest to the known localities where the wild species grow.

- In situ experiments in cooperation with local growers, thanks to their high potential agronomic value and high tolerance to drought, insects, and high content of glucosinolate $[95,96]$.

- In situ and ex situ crosses with cultivated B. oleracea, although some preliminary studies have shown low fertility values of crosses between $B$. montana and cultivated forms of B. oleracea [87]. The wild populations could be maintained with low onsite management because they grow on cliff sites and suffer especially due to the availability of nutrients.

- Ex situ conservation of wild populations is necessary, especially to avoid species extinction or further genetic erosion after ecological changes [97], and can be realized by plant conservation in botanical gardens and seed-banks, the latter started by Gomez-Campo and Gustafsson in 1986 [82]. 
- Low levels of observed heterozygosity in natural populations of B. insularis document the importance of developing conservation guidelines appropriate for the populations of this species [82]. Geographical variation studies might be further investigated with physiological analyses [98].

- Monitoring of known populations and field surveys to find new sites (especially for B. insularis). Despite the restriction on collecting B. insularis from the known sites, the cleaning of cliffs to create suitable climbing areas could be a problem. Preventing access to the $B$. insularis populations appears to be the most suitable conservation measure with the support of protection policies, which was how it was achieved for the Corsica populations [82].

- Ecological studies are needed to determine the role of grazing (especially by goats) on population maintenance [99].

- Phytosociological studies in Italy, where it occurs, to evaluate vegetation, habitat, ecology, and biodiversity, especially for B. insularis for which there is a lack of data.

\subsection{Crambe hispanica L. subsp. hispanica, Crambe tataria Sebeók subsp. tataria (Policy Species)}

Many species of the genus Crambe L. are considered industrial crops [100]. For instance, C. tataria can be used for paper production when mixed with long fibrous materials [101], to obtain higher oil and erucic acid yield [102]; C. hispanica was used for the production of special lubricants, in industrial vulcanization processes, and in those that lead to erucamide from erucic acid [103-105], biodiesel, meal and husk for animal feed [106]. For this purpose, in 1975, C. hispanica seed samples were collected in Apulia (Gargano) and Sardinia by a team of breeders from California (U.S.A.) and agronomists from the Germoplasm Istitute of Bari (CNR) [107], for its cultivation as a new alternative crop to other industrial crops [108,109].

The genus Crambe has an extensive area of distribution that goes from the Macaronesian archipelagoes to the west of China and north of India, and from the Arctic Polar Circle on the Scandinavian Peninsula to $5^{\circ}$ latitude south in the northern Tanzania. It is well-represented in the Macaronesian, Euro-Siberian, Mediterranean, Sindico-Saharan, Irano-Turkish and Sudan-Zambezian (Ethiopia and Tanzania) regions [103] and includes more than 35 species [110,111]. Based mainly on the dimensions and shape of the proximal joint of the fruit, the genus is divided in three sections (Crambe, Dendrocrambe and Leptocrambe) that closely correspond to the geographical areas of distribution [112,113]. In Italy, only two species of Crambe are present [17], both considered CWRs [1]: C. hispanica subsp. hispanica (section Leptocrambe) and C. tataria subsp. tataria (section Crambe).

C. hispanica subsp. hispanica is a south Mediterranean-Turanian entity reported in northern Ethiopia [103], Morocco, Portugal, Spain, former Yugoslavia (Serbia and Montenegro), Greece, Cyprus, Lebanon, Syria, Israel, Jordan, Italy [114], Turkey [115], and Albania [116]. The Italian distribution sites are described in the study of Perrino et al. [30], and concern well-defined areas of Apulia, Calabria, Sicily, and Sardinia, while the presence in Basilicata is doubtful [17].

C. tataria subsp. tataria is endemic to the Pontic-Pannonian region, with a strong disjunction from its main distributional range in the Friuli-Venezia Giulia region, the only site in Italy [117].

C. hispanica subsp. hispanica is a sub-nitrophilic-synanthropic species, which in Italy grows on calcareous soils, on sandy soils of volcanic origin, and on brown soils, exclusively in habitats subject to anthropic disturbance and semi-rupestrian environments. It can be located at the edge of abandoned olive groves, near lake basins, along dry-stone walls, in the shade of isolated trees, often of Quercus trojana Webb ascribed to the Crambetum hispanicae Perrino, Tomaselli, Signorile, Angiulli, Silletti 2011 association [118], along the banks of rivers [119], in shrub vegetation dominated by Cytisus villosus Pourr. and Spartium junceum L., to margins of thermophilous woods, in uncultivated arid areas [120], and also in correlation with road bumps. In the Apulian populations, it grows on calcareous substrates, with a certain enrichment, never very intense, in soil nutrients, while in Sicily the species prefers humid environments and on Mt. Etna, where the best-preserved Sicilian 
populations occur, it grows on shallow and very humified soils [121]. The flowering time of C. hispanica subsp. hispanica in Italy is from March to April.

C. tataria subsp. tataria is reported on steppes and hills rich in clay and limestone from eastern Europe to the Caucasus [113]. In Italy, it grows on extensive deep beds of alluvial, calcareous gravel deposited by the rivers Cellina and Meduna that characterize the "magredi" landscape. The use of land for military purposes in sparsely inhabited areas has somehow helped in the preservation of "magredi" fragments, where C. tataria is one of the most typical elements of this characteristic grassland formation [117] referred to Centaureo dichroanthae-Globularietum cordifoliae Pignatti 1953 association [122] which is considered habitat 92/43/EEC "Eastern sub-mediterranean dry grasslands (Scorzoneretalia villosae)" (code 62A0). The flowering time of $C$. tataria subsp. tataria in Italy is from May to June.

The chromosome number is $2 \mathrm{n}=60$ in C. hispanica subsp. hispanica [99] and $2 \mathrm{n}=30$ in C. tataria subsp. tataria [123].

C. hispanica subsp. hispanica and C. tataria subsp. tataria are both reported as threatened in Italy, while they are considered LC in the European Red List (Table 1). Both species have a high in situ priority (A). As for ex situ conservation, C. tataria subsp. tataria with one accession has normal priority (NP), and C. hispanica subsp. hispanica with five accessions has no priority (ZP) [16] (Table 2), although the number of accessions is still low. In addition, C. hispanica subsp. hispanica is important for its primary gene pool (GP1) (Table 3). However, independently from the gene pool, $C$. tataria also needs widespread protection because it is rare throughout the global range and its habitats are often destroyed; in fact, the taxon is also reported in the Red Books of the USSR and Kazakhstan [124].

\section{Expected Actions}

- In situ and ex situ conservation to prevent the risk of extinction by increasing the number of individuals in wild populations. For C. hispanica subsp. hispanica, an ex situ conservation strategy is strongly needed to support the industrial purposes as an oil plant, through on farm conservation, while as for in situ conservation, research to learn more about the breeding system and the vertical pollen transfer is needed [121].

- In situ conservation is the most appropriate strategy for C. tataria subsp. tataria, although some in vitro regeneration studies [117] suggest a possible long-term conservation of plant tissue by ex situ strategies.

- Habitat conservation at the global level is very helpful because $C$. tataria grows in different habitats of the 92/43/EEC directive of several countries where it is reported, such as Italy (Eastern sub-Mediterranean dry grasslands (Scorzoneretalia villosae) (code 62A0)), Romania (Sub-Pannonic steppic grasslands $\left(6240^{*}\right)$ and Ponto-Sarmatic steppes (code 62C $0^{*}$ ) [125], and Kazakhstan (Semi-natural dry grasslands and scrubland facies on calcareous substrates (Festuco-Brometalia) (code 6210*)) [126].

- The man-made summer fires with the aim to clean the soil in the habitat of $C$. hispanica subsp. hispanica (Crambetum hispanicae), when not avoidable, must be targeted to the dry component of the plant and carried out from the end of July, after the period of seed dissemination (May-June), otherwise the plants could be irreversibly damaged. As for the populations growing along the road, it is crucial that bodies responsible for road management be informed about the presence of threatened species. The species in question is linked to abandoned or extensively managed agricultural areas, which have a good naturalness (defined HNVF, high nature value farmland) due to the immediate proximity of shrubland or woodland vegetation. Therefore, one of the main threats to the survival of the species and its plant community is the current trend to use high impact agriculture, including chemical input, such as herbicides.

- Monitoring of known populations for both species.

- Maintenance of $C$. hispanica subsp. hispanica in Botanical Gardens for educational purposes.

- Genetic research (ad hoc) to define the gene pools of $C$. tataria subsp. tataria. 


\subsection{Ipomoea sagittata Poir}

The genus Ipomoea L. has an amphi-Atlantic distribution, and probably it arrived in Europe only after contact with the new world [127], with 18 known species [128]. I. sagittata is known in the eastern Atlantic and the Mediterranean region from Algeria, the Balearic Islands, Corsica, Cyprus, Greece, Lebanon, Italy, Malta, Portugal, Sicily, Spain, Syria, Tunisia, and Turkey [128]. Austin [129] suggests that I. sagittata is native to the circumCaribbean region of the Americas, and it probably arrived in Europe for the first time in Greece or France by sea with maritime trade and then it spread to other Mediterranean territories. Other authors [130] believe that seed dispersion had been mediated through ocean currents, and this would probably explain why I. sagittata grows in salt marshes, and could have made it to Europe in prehistoric times. Thus, we can conclude that due to the large disjunction in its distribution it is a controversial species, because even if introduced a long time ago, it probably is an exotic wild species [131]. As a result, its nativity needs to be re-evaluated.

In Italy, I. sagittata grows with other ten species of the same genus: I. imperati (Vahl) Griseb. (=I. stolonifera (Cyr.) J.F.Gmel.) [17,132] and nine exotic taxa (I. batatas (L.) Lam., I. cairica (L.) Sweet, I. coccinea L., I. indica (Burm.) Merr., I. pandurata (L.) G.Mey., I. purpurea (L.) Roth, I. tricolor Cav., I. triloba L.) [133], and Ipomoea setosa Ker-Gawl. subsp. pavonii (Hallier f.) J.R.I. Wood \& Scotland [62]. The Italian distribution of I. sagittata includes the Latium, Apulia, Calabria, and Sicily regions [17].

I. sagittata is a rhizomatous geophyte flowering from June to September, typical of coastal marshes and wet brackish muds and banks [134], and is always very localized in Italy and threatened by the rarity and vulnerability of the environments in which it grows, as shown by its disappearance in historic sites such as those of the coast of Mondello (Palermo-Sicily), "Pantano del Taro" (Taranto-Apulia) and on the islet of "S. Nicolicchio" (Taranto-Apulia) for reasons related to human activity [134]. Fortunately, botanical explorations have made it possible to discover new stations in the Salento peninsula (Apulia region), such as those at "Le Cesine" [135] "Palude di Rauccio" (Lecce) [136], "Laghi Alimini" [137], "Torre Rinalda", Basins of Ugento, at "Punta Prosciutto" in the "Palude del Conte" [134], and "Torre Chianca" [138], in many localities in the Province of Trapani (Sicily), such as "Isola Grande dello Stagnone" [139], "Santa Ninfa" [140], "Petrosino" along the drainage canals [141], and near the halophilous reeds of "Lago Prato" in the province of Catanzaro (Calabria) [142]. It is confirmed along the southern edges of "Lago Fondi" and "Canale S. Anastasia" into the Regional Natural Park of "Monti Ausoni e Lago di Fondi" in the Lazio region [143].

The chromosome number is $2 \mathrm{n}=30$ (from accessions of Pali district in India) [144]; it has been reported with a synonym (=I. sagittifolia Ker Gawl.) and with interesting information of $77 \%$ of pollen fertility.

This species is listed as VU in the European Red List and as EN in the Italian National Red List (Table 1), with high priority in situ (A) and ex situ (HP) conservation (Table 2), while there are no data about gene pool (Table 3). It is worth noting that despite its limited Italian distribution, the species grows in several wetland types of vegetation as companion species, i.e., Spartino-Juncetum maritimae O. Bolòs 1962, Soncho maritimi-Cladietum marisci (Br.-Bl. \& O. de Bolòs 1957) Cirujano 1980 [145], Rubo ulmifolii-Myrtetum communis Biondi \& Bagella 2005, Schoeno nigricantis-Plantaginetum crassifoliae Br.-Bl. in Br.-Bl., Roussine \& Nègre 1952, Schoeno nigricantis-Erianthetum ravennae Pignatti 1953 [146] all observed in the Salento peninsula, and Ranunculetum peltati Sauer 1947 at Anguillara (Trapani) in Sicily [147]. It is also considered a diagnostic taxon of the alliance Calystegion sepium Tüxen ex Oberdorfer 1957 nom. mut. propos. Rivas-Martínez, T.E. Díaz, Fernandez-Gonzales, Izco, Loidi, Lousã \& Penas 2002, which encloses the nitrophilous tall-herb communities that develop in humid, periodically inundated, habitats and are subjected to long periods of drainage and occasionally with a moderate salinity [18]. This peculiar type of vegetation is reported in Annex I of the Habitat Directive 92/43/ECC as "Hydrophilous tall herb fringe communities of plains and of the montane to alpine levels" (code 6430) (Table 2). 
It has been observed that, in North America, I. sagittata can be harmful for agricultural purposes because it harbors an insect, "the weevil", that can infest crop potato, although found only in limited sections of the sweet potato-growing areas, mostly in the coastal and tide-marsh margins [148]. There are no recorded medicinal uses of I. sagittata in the Old World [129], and there are doubts that it is a real CWR, as indicated by Bilz et al. [24].

\section{Expected Actions}

- Clarify with ad hoc studies and researchers (including historical ones) if the taxon is exotic or native in Europe.

- Monitoring of populations in known areas and field surveys to find new sites, especially in the Lazio region, where there are few sites.

- Ex situ germplasm conservation is needed because it has zero accessions in the RIBES seed banks, but in situ conservation actions are also important, especially where it is highly threatened.

- $\quad$ Research on gene pools and the content of microelements is welcome.

- Interviews, where the taxon is more widespread (e.g., in Salento), to check possible uses.

\subsection{Lathyrus amphicarpos L., Lathyrus palustris L.}

Some species of genus Lathyrus L. play an important role in the improvement of cultivated crops. According to the first results of interspecific hybridization, the closest allies of L. sativus Sibth. \& Sm. ex Steud. (grasspea) were L. amphicarpos and L. cicera L. recorded in the secondary gene pool (GP2) of the grasspea [149,150]. Heywood et al. [151] extended the secondary gene pool also to L. chrysanthus Boiss., L. gorgoni Parl., L. marmoratus Boiss. \& Balansa ex Boiss. and L. pseudocicera Pamp., with which L. sativus can cross and produce ovules, and more remotely to L. amphicarpos, L. blepharicarpus Boiss., L. chloranthus Boiss. \& Balansa, L. cicera, L. hierosolymitanus Boiss. and L. hirsutus L., with which L. sativus can cross to form pods. L. gorgoni and L. hirsutus are also reported in Italy [17]. The remaining species of the genus can be considered members of the tertiary gene pool (GP3) [152]. The results of electrophoretic comparative analysis of seed albumins and globulins showed $L$. satious to be considerably different from the allied species. Consequently, exploitation of the germplasm resources in the breeding improvement programs of the grasspea should be concentrated on the primary gene pool (GP1), as suggested by Yunus and Jackson [150].

L. palustris is a perennial plant and natural autohexaploid, having $2 \mathrm{n}=6 \times=42$ chromosome [153], while L. amphicarpos has a $2 \mathrm{n}=14$ chromosome [154].

L. amphicarpos is a Mediterranean taxon which occurs in Algeria, the Balearic Islands, France (Corsica), Greece, Crete, Italy, Morocco, Portugal, and Spain, while L. palustris has a wider distribution, being a circumboreal taxon [155]. In Italy, L. amphicarpos grows only in the Sicily, Apulia, and Latium regions, while L. palustris has a fragmentary distribution in the northern regions and is absent in the Center-South of the Italian Peninsula [17]. $L$. amphicarpos grows in Latium on arid meadows and garrigues from 250 up to $600 \mathrm{~m}$ a.s.l. in the Ausoni chain on Mt. Leano [156], Mt. Cucca, M. Cavallo Bianco and M. Saiano [157], in the Natural Reserve "Pizzo Cane, Pizzo Trigna and Grotta Mazzamuto" (north-west of Sicily) [158], in other sites of Palermo municipality, at Monte Sparacio (Trapani) on Nebrodi mountains (Messina) in Sicily [159], and in the southern sector of the Daunia Mountains in Apulia [160].

Among wild species of genus Lathyrus, L. amphicarpos showed the best antioxidant activity results in seed methanolic extracts [161] and higher total saturated fatty acids. These data, combined with the benefits attributable to the secondary metabolites (polyphenol contents), suggests the use of the genus Lathyrus, and in particular of L. amphicarpos, in human and animal diets [162]. L. palustris also has favorable histological characteristics for use as a fodder crop [154,163].

L. amphicarpos is listed as NT in the European Red List and as LR in the Italian National Red List (Table 1), with high in situ (A) and high ex situ (HP) priority (Table 2), and as a secondary gene pool (GP2) (Table 3) giving rise viable hybrids in crosses with 
L. sativus [150,164]; while L. palustris is listed as EN in the Italian Red List (Table 1), with high in situ (A) and ex situ priority (HP) (Table 2), and with no information on gene pool (Table 3).

L. amphicarpos is an annual plant with an elongated flower axis, often without leaves, that flowers from March to April, from sea level to $600 \mathrm{~m}$ of altitude. The only ecological information in Italy comes from Sicily, where the species is found in limestone and stony ground with sparse vegetation of annual species located in degraded Ampelodesmos mauritanicus (Poir.) T. Durand \& Schinz grasslands subjected to the action of fire and grazing, and in stations exposed to the action of atmospheric elements that cause soil erosion. In these habitats, the species spreads its slender roots among the stones, developing the phenomenon of amphicarpy, a typical adaption in acid habitats, subject to fire [159].

L. palustris is a perennial plant that flowers from June to August, from sea level to $800 \mathrm{~m}$ of altitude, for which little ecological data are available, especially about the vegetation in which it grows. In Alto Adige, it is observed in the humid, uncultivated grasslands of the Molinion caeruleae Koch 1926 alliance [165], attributable to the habitat 92/43/EEC "Molinia meadows on calcareous, peaty or clayey-silty soils (Molinion caeruleae)" (code 6410), although it is a diagnostic of the "Mediterranean high and humid herbaceous grasslands of Molinio-Holoschoenion" habitat (code 6420) [166]. However, there is a gap in phytosociological studies for this species.

Expected Actions

- In situ and ex situ conservation to prevent the risk of extinction by increasing the number of existing wild populations for both Lathyrus species.

- Use in the human diet of L. amphicarpos due to good antioxidant activity present in their seeds and for the presence of high content of saturated fatty acids [162], but only after research and breeding with the aim to turn saturated fat to unsaturated fat acid content.

- Monitoring the known populations of L. amphicarpos and field surveys to find new sites because of the earlier confusion with L. cicera, which is very similar in morphology, although much more widespread in Italy.

- Specific ecological studies on L. palustris wetlands habitats, which could provide information on factors related to the maintenance of wetlands and their conservation, considering the potential benefit of use as grazing fodder, especially for buffalo [167].

- Ecological and phytosociological studies for L. amphicarpos, because information available in the literature is poor.

\subsection{Vicia cusnae Foggi \& Ricceri, Vicia serinica R. Uechtr. et Huter}

$V$. cusnae and $V$. serinica are two orophytes, systematically closed and belonging to a group formed also by $V$. canescens Labill. (Makmel massif in Lebanon), $V$. variegata Willd. (Erzerum mountains in Turkish Armenia), and V. argentea Lapeyr. (Central Pyrenees) [168], and can be considered geographic vicariants among themselves [169], although there are different readings, such as that of Davis [170], which consider V. serinica and V. variegata as a subspecies of $V$. canescens. There are several morphological differences between the species of the group that concern microcharacters located in different parts of the plant [169].

V. cusnae is reported in three circumscribed sites: two in Italy, in the National Park of the Tuscan-Emilian Apennines (Emilia Romagna Region), at M. Cusna [169] and at Rio Re at M. Prado [171]; and, thanks to Philippe Küpfer, in France in the Aurouze Massif [23]. V. serinica is reported in southern Italy and in northern Greece [172]. In Greece, it was collected by Gustavsson in several mountains at Sterea Ellas, by Aldén from Mount Kakarditsa in Pindhos [173], and by Strid and Papanicolaou [174] on Mt. Belles (Kerkini), north-east of the village of Ano Poroia. In Italy, it occurs only in a very confined area of Basilicata region, while it was reported by mistake in Campania [17]. In Basilicata, it grows in only four stations of Sirino-Papa Massif $[175,176]$, in the municipality of Potenza (confirmed by E.V. Perrino, unpubl. data).

$V$. cusnae and $V$. serinica have both the same chromosomal number $(2 \mathrm{n}=10)$, just like the other three species of the group [169]. This datum can be interpreted as schizoen- 
demisms, with puntiform distribution and geographically isolated [177], that make highly improbable genetic exchanges between the populations of these two species with the other conspecific populations.

V. cusnae is an alpine glareicole taxon that flowers from July to August on detrital soils of sedimentary rocks with southern exposure and in xerothermic conditions, from 1800 to $2100 \mathrm{~m}$ of altitude [23]. It reproduces mainly by vegetative parts, thanks to the presence of short underground stolons, which issue new close shoots [23], as was also observed for V. serinica at M. Sirino (observed by E.V. Perrino, unpubl. data), rather than by seed dispersal [178]. It covers large areas in which it is a dominant taxon, and it is assigned to the Thlaspion rotundifolii Jenny-Lips 1930 alliance [179] and habitat 92/43/EEC "Calcareous rocky slopes with chasmophytic vegetation" (code 8210).

$V$. serinica flowers in July on soils similar to those of V. cusnae, from 1500 to $1850 \mathrm{~m}$ of altitude, colonizing peculiar niches reserved for highly specialized species that are able to grow in extreme environmental conditions. The soil has a copious skeleton in the superficial horizons and a high sand content in all layers. The annual average precipitation is about $1400 \mathrm{~mm}$, while the bioclimate is oceanic temperate of the humid supratemperate type [176]. The vegetation of $V$. serinica is referred to be Sideridenion italicae Biondi et al. 1995 corr. Biondi, Allegrezza \& Zuccarello 2005 sub-alliance, with a conspicuous number of species of the Thlaspietalia rotundifolii Br.-Bl. In Br.-Bl. et Jenny 1926 order [176], to be related to the priority habitat $92 / 43 / \mathrm{EEC}$ "Semi-natural dry grasslands and scrubland facies on calcareous substrates (Festuco-Brometalia) (*important orchid sites)" (code 6210*) [38].

$V$. cusnae and V. serinica are listed as VU [25] and EN [32], respectively, in the Italian Red List (Table 1), with high in situ (A) and ex situ priority (HP) (Table 2). There are no available data on their gene pools (Table 3).

\section{Expected Actions}

- Research in situ with monitoring programs to better understand the reproductive biology and ecology of the species and the populations trends.

- Evaluate ecological and genetic affinities between the different populations of both species.

- Phytosociological studies to define the phytosociological association and discover why similar environments produce different types of vegetation and habitats.

- Ex situ conservation for both species. For V. cusnae it is possible, because it is an orthodox species, which means that it tolerates seed drying with high levels of germination (80\%) after scarification, at $21^{\circ} \mathrm{C}$ [180]. The only germplasm accessions of $V$. cusnae are preserved at the Millennium Seed Bank of the Royal Botanic Gardens in Kew (U.K.) and those of $V$. serinica in the seed bank collections of the Institute of Biosciences and Bioresources (IBBR-CNR) of Bari, but both are absent in RIBES seedbanks.

- $\quad$ Start crossbreeding studies with $V$. sativa L., whose seeds are consumed by birds and often used as forage, to test their gene pools and to check their taxonomy and systematics.

\section{Conclusions}

In Italy, according to the taxon group concept, there are 43 CWRs at risk of inadequate conservation either in situ or ex situ. However, disregarding the species endemic to Italy, the number of 43 falls to 14. Furthermore, according to the gene pool concept, which is more important from a plant breeding point of view, the number 14 falls to 8 . For these latter species, this paper provides a picture as complete as possible about their geographical distribution, level of protection, ecology (including vegetation and habitat 92/43 EEC), properties, gene pools, and actions to avoid further genetic erosion, to improve in situ and ex situ conservation of the species and habitats, with the final goal of enhancing genetic resources management and their use both in plant breeding and to promote sustainable agriculture and environmental conservation through ad hoc research, suggested for each of the 14 CWRs considered at risk. 
Author Contributions: Conceptualization, methodology and investigation, E.V.P.; validation, formal analysis, and data curation, E.V.P. and R.P.W.; writing - original draft preparation, E.V.P.; writingreview and editing, E.V.P. and R.P.W. The authors have read and agreed to the published version of the manuscript.

Funding: This study was financially supported by the University of Bari "Aldo Moro".

Institutional Review Board Statement: Not applicable.

Informed Consent Statement: Informed consent was obtained from all subjects involved in the study.

Data Availability Statement: Not applicable.

Conflicts of Interest: The authors declare no conflict of interest.

\section{References}

1. Perrino, E.V.; Perrino, P. Crop wild relatives: Know how past and present to improve future research, conservation and utilization strategies, especially in Italy: A review. Genet. Resour. Crop Evol. 2020, 67, 1067-1105. [CrossRef]

2. Zair, W.; Maxted, N.; Brehm, J.M.; Amri, A. Ex situ and in situ conservation gap analysis of crop wild relative diversity in the Fertile Crescent of the Middle East. Genet. Resour. Crop Evol. 2020, 68, 693-709. [CrossRef]

3. Maxted, N.; Ford-Lloyd, B.V.; Kell, S.P. Crop wild relatives: Establishing the context. In Crop Wild Relative Conservation and Use; Maxted, N., Ford-Lloyd, B.V., Kell, S.P., Iriondo, J., Dulloo, E., Turok, J., Eds.; CAB International: Wallingford, UK, 2008.

4. Maxted, N.; Kell, S. Establishment of a Network for the In Situ Conservation of Crop Wild Relatives: Status and Needs; Commission on Genetic Resources for Food and Agriculture; Food and Agriculture Organization of the United Nations: Rome, Italy, 2009.

5. Pimentel, D.; Wilson, C.; McCullum, C.; Huang, R.; Dwen, P.; Flack, J.; Tran, Q.; Saltman, T.; Cliff, B. Economic and environmental benefits of biodiversity. BioScience 1997, 47, 747-757. [CrossRef]

6. Phillips, O.L.; Meilleur, B. Usefulness and economic potential of the rare plants of the United States: A status survey. Econ. Bot. 1998, 52, 57-67. [CrossRef]

7. Maxted, N.; Ford-Lloyd, B.V.; Jury, S.L.; Kell, S.P.; Scholten, M.A. Towards a definition of a crop wild relative. Biodivers. Conserv. 2006, 15, 2673-2685. [CrossRef]

8. Kell, S.P.; Knüpffer, H.; Jury, S.L.; Ford-Lloyd, B.V.; Maxted, N. Crops and wild relatives of the Euro-Mediterranean region: Making and using a conservation catalogue. In Crop Wild Relative Conservation and Use; Maxted, N., Ford-Lloyd, B.V., Kell, S.P., Iriondo, J., Dulloo, E., Turok, J., Eds.; CAB International: Wallingford, UK, 2008.

9. Harlan, J.R.; de Wet, J.M.J. Towards a rational classification of cultivated plants. Taxon 1971, 20, 509-517. [CrossRef]

10. Jarvis, A.; Lane, A.; Hijmans, R.J. The effect of climate change on crop wild relatives. Agric. Ecosyst. Environ. 2008, 126, 13-23. [CrossRef]

11. McCouch, S.; Baute, G.J.; Bradeen, J.; Bramel, P.; Bretting, P.K.; Buckler, E.; Burke, J.M.; Charest, D.; Cloutier, S.; Cole, G.; et al. Agriculture: Feeding the future. Nature 2013, 499, 23-24. [CrossRef]

12. Hunter, D.; Heywood, V. Crop Wild Relatives: A Manual of In Situ Conservation; Biodiversity International: Rome, Italy, 2012.

13. Vincent, H.; Amri, A.; Castañeda-Álvarez, N.P.; Dempewolf, H.; Dullo, E.; Guarino, L.; Hole, D.; Mba, C.; Toledo, A.; Maxted, N. Modeling of crop wild relative species identifies areas globally for in situ conservation. Commun. Biol. 2019, 2, 136. [CrossRef]

14. Khaki Mponya, N.; Chanyenga, T.; Magos Brehm, J.; Maxted, N. In situ and ex situ conservation gap analyses of crop wild relatives from Malawi. Genet. Resour. Crop Evol. 2020, 68, 759-771. [CrossRef]

15. FAO. International Treaty on Plant Genetic Resources for Food and Agriculture; Food and Agriculture Organization of the United Nations: Rome, Italy, 2001.

16. Magrini, S.; Atzeri, P.; Bacchetta, G.; Bedini, G.; Carasso, V.; Carta, A.; Ceriani, R.; Ciancaleoni, S.; Di Martino, L.; Di Santo, M.; et al. The Conservation of the Italian Crop Wild Relatives in the RIBES Seedbanks: First Data to Establish National Inventories and Conservation Priorities. In The RIBES Seed-Banks for the Conservation of the Crop Wild Relatives (CWR); Mariotti, M., Magrini, S., Eds.; RIBES Series 2; IRIS UniPA: Palermo, Italy, 2016; Volume 2, pp. 7-18. Available online: https://iris.unipa.it/retrieve/handle/10 447/231481/425888/Magrini\%20et\%20al.,\%202016.pdf (accessed on 23 October 2020).

17. Bartolucci, F.; Peruzzi, L.; Galasso, G.; Albano, A.; Alessandrini, A.; Ardenghi, N.M.G.; Astuti, G.; Bacchetta, G.; Ballelli, S.; Banfi, E.; et al. An updated checklist of the vascular flora native to Italy. Plant Biosyst. 2018, 152, 179-303. [CrossRef]

18. Biondi, E.; Blasi, C. Prodromo Della Vegetazione d'Italia. Check-List Sintassonomica Aggiornata di Classi, Ordini e Alleanze Presenti in Italia; Società Botanica Italiana Onlus: Roma, Italy, 2013. Available online: http:/ /www.prodromo-vegetazione-italia.org (accessed on 20 November 2020).

19. Rivas-Martínez, S. Global Bioclimatics. Clasificación Bioclimática de la Tierra, 2004. Available online: http://www. globalbioclimatics.org/book/bioc/bioc1.pdf (accessed on 21 October 2020).

20. ISTAT. Consultazione Dati. 2012. Available online: http:/ /agri.istat.it (accessed on 10 December 2012).

21. Conti, F.; Manzi, A.; Pedrotti, F. Libro Rosso delle Piante d'Italia; Ministero Ambiente, WWF Italia, Società Botanica Italiana: Roma, Italy, 1992. 
22. Conti, F.; Manzi, A.; Pedrotti, F. Liste Rosse Regionali delle Piante d'Italia; WWF Italia, Società Botanica Italiana, CIAS: Camerino, Italy, 1997.

23. Foggi, B.; Rossi, G.; Gentili, E.R. Schede per una Lista Rossa della Flora vascolare e crittogamica Italiana: Vicia cusnae Foggi et Ricceri. Inform. Bot. Ital. 2008, 40, 124-126.

24. Bilz, M.; Kell, S.P.; Maxted, N.; Lansdown, R.V. European Red List of Vascular Plants; Publications Office of the European Union: Luxembourg, 2011.

25. Rossi, G.; Montagnani, C.; Gargano, D.; Peruzzi, L.; Abeli, T.; Ravera, S.; Cogoni, A.; Fenu, G.; Magrini, S.; Gennai, M.; et al. Lista Rossa della Flora Italiana. 1. Policy Species e Altre Specie Minacciate; Comitato Italiano IUCN, Ministero dell'Ambiente e della Tutela del Territorio e del Mare, Stamperia Romana: Roma, Italy, 2013.

26. Rossi, G.; Orsenigo, S.; Montagnani, C.; Fenu, G.; Gargano, D.; Peruzzi, L.; Wagensommer, R.P.; Foggi, B.; Bacchetta, G.; Domina, G.; et al. Is legal protection sufficient to ensure plant conservation? The Italian Red List of policy species as a case study. Oryx 2016, 50, 431-436. [CrossRef]

27. Perrino, E.V.; Wagensommer, R.P. Schede per una Lista Rossa della Flora vascolare e crittogamica Italiana: Aegilops uniaristata Vis. Inform. Bot. Ital. 2012, 44, 201-203.

28. Perrino, E.V.; Wagensommer, R.P. Schede per una Lista Rossa della Flora vascolare e crittogamica Italiana: Aegilops biuncialis Vis. Inform. Bot. Ital. 2013, 45, 119-121.

29. Perrino, E.V.; Wagensommer, R.P. Schede per una Lista Rossa della Flora vascolare e crittogamica Italiana: Aegilops ventricosa Tausch. Inform. Bot. Ital. 2013, 45, 323-326.

30. Perrino, E.V.; Russo, G.; Turrisi, R.E.; Tomaselli, V.; Wagensommer, R.P. Schede per una Lista Rossa della Flora vascolare e crittogamica Italiana: Crambe hispanica L. Inform. Bot. Ital. 2013, 45, 354-357.

31. Santo, A.; Fenu, G.; Domina, G.; Bacchetta, G. Schede per una lista rossa della flora vascolare e crittogamica italiana: Brassica insularis Moris. Inform. Bot. Ital. 2013, 45, 127-130.

32. Orsenigo, S.; Fenu, G.; Gargano, D.; Montagnani, C.; Abeli, T.; Alessandrini, A.; Bacchetta, G.; Bartolucci, F.; Carta, A.; Castello, M.; et al. Red list of threatened vascular plants in Italy. Plant Biosyst. 2020. [CrossRef]

33. Convention on the Conservation of European Wildlife and Natural Habitats (1979) Adopted in Berne 19 September 1979. Available online: https: / / www.coe.int/en/web/bern-convention (accessed on 19 November 2020).

34. European Commission. Council Directive 92/43/EEC of 21 May 1992 on the Conservation of Natural Habitats and of Wild Fauna and Flora, 1995-2007. Available online: http:/ / eurlex.europa.eu/LexUriServ /LexUriServ.do?uri=CELEX:31992L0043:EN:HTML (accessed on 19 November 2020).

35. Landucci, F.; Panella, L.; Lucarini, D.; Gigante, D.; Donnini, D.; Kell, S.; Maxted, N.; Venanzoni, R.; Negri, V. A prioritized inventory of crop wild relatives and wild harvested plants of Italy. Crop Sci. 2014, 54, 1628-1644. [CrossRef]

36. Vincent, H.; Wiersema, J.; Kell, S.; Fielder, H.; Dobbie, S.; Castañeda-Álvarez, N.P.; Guarino, L.; Eastwood, R.; León, B.; Maxted, N. A prioritized crop wild relative inventory to help underpin global food security. Biol. Conserv. 2013, 167, 265-275. [CrossRef]

37. Orsenigo, S.; Montagnani, C.; Fenu, G.; Gargano, D.; Peruzzi, L.; Abeli, T.; Alessandrini, A.; Bacchetta, G.; Bartolucci, F.; Bovio, M.; et al. Red Listing plants under full national responsibility: Extinction risk and threats in the vascular flora endemic to Italy. Biol. Conserv. 2018, 224, 213-222. [CrossRef]

38. Biondi, E.; Blasi, C.; Burrascano, S.; Casavecchia, S.; Copiz, R.; Del Vico, E.; Galdenzi, D.; Gigante, D.; Lasen, C.; Spampinato, G.; et al. Italian Interpretation Manual of the Habitats (92/43/EEC Directive); Ministry of Environment, Land and Sea Protection, 2010. Available online: http://vnr.unipg.it/habitat/ (accessed on 18 November 2020).

39. Thiyagarajan, K.; Latini, A.; Cantale, C.; Galeffi, P. Structural characterization of the DRF1 gene of Aegilops speltoides and comparison of its sequence with those of B and other Triticeae genomes. Euphytica 2020, 216, 152. [CrossRef]

40. Cakmak, I. Enrichment of cereal grains with zinc: Agronomic or genetic biofortification? Plant Soil 2007, 302, 1-17. [CrossRef]

41. Black, R.E.; Victora, C.G.; Walker, S.P.; Bhutta, Z.A.; Christian, P.; de Onis, M.; Ezzati, M.; Grantham-McGregor, S.; Katz, J.; Martorell, R.; et al. Maternal and child undernutrition and overweight in low-income and middle-income countries. Lancet 2013, 382, 427-451. [CrossRef]

42. Velu, G.; Singh, R.P.; Crespo-Herrera, L.; Juliana, P.; Dreisigacker, S.; Valluru, R.; Stangoulis, J.; Singh Sohu, V.; Singh Mavi, G.; Mishra, V.K.; et al. Genetic dissection of grain zinc concentration in spring wheat for mainstreaming biofortification in CIMMYT wheat breeding. Sci. Rep. 2018, 8, 13526. [CrossRef]

43. Cakmak, I.; Pfeiffer, W.H.; Mcclafferty, B. Biofortification of durum wheat with zinc and iron. Cereal Chem. 2010, 87, 10-20. [CrossRef]

44. Rawat, N.; Tiwari, V.K.; Singh, N.; Randhawa, G.S.; Singh, K.; Chhuneja, P.; Dhaliwal, H.S. Evaluation and utilization of Aegilops and wild Triticum species for enhancing iron and zinc content in wheat. Genet. Resour. Crop Evol. 2009, 56, 53-64. [CrossRef]

45. Loureiro, I.; Escorial, M.C.; García-Baudin, J.M.; Chueca, M.C. Hybridization between wheat (Triticum aestivum) and the wild species Aegilops geniculata and A. biuncialis under experimental field conditions. Agric. Ecosyst. Environ. 2006, 120, 384-390. [CrossRef]

46. Chennaveeraiah, M.S. Karyomorphologic and Cytotaxonomic Studies in Aegilops. Acta Hort. Gothoburg. 1960, $23,89-231$.

47. Waines, J.G.; Barnhart, D. Biosystematic research in Aegilops and Triticum. Hereditas 1992, 116, 207-212. [CrossRef]

48. Bogdanović, S.; Ljubičić, I.; Clementi, M. Aegilops uniaristata Vis. (Poaceae): Typification and occurrence in Croatia. Acta Bot. Croat. 2015, 74, 1-8. [CrossRef] 
49. Cabi, E.; Dogan, M.; Özler, H.; Akaydin, G.; Karagöz, A. Taxonomy, morphology and palynology of Aegilops vavilovii (Zhuk.) Chennav. (Poaceae: Triticeae). Afr. J. Agric. Res. 2010, 5, 2841-2849.

50. Perrino, E.V.; Wagensommer, R.P.; Medagli, P. The genus Aegilops L. (Poaceae) in Italy: Taxonomy, geographical distribution, ecology, vulnerability and conservation. Syst. Biodivers. 2014, 12, 331-349. [CrossRef]

51. Zaharieva, M.; Monneveux, P. Spontaneous hybridization between bread wheat (Triticum aestivum L.) and its relatives in Europe. Crop Sci. 2006, 46, 512-527. [CrossRef]

52. Perrino, E.V. New data on Aegilops uniaristata Vis. endangered taxon in Italy. Nat. Croat. 2011, 20, 117-123.

53. Bellakhdar, J. La Pharmacopée Marocaine Traditionnelle: Médecine Arabe Ancienne et Savoir Populaires; Ibis Press: Paris, France, 1997.

54. Abderrahim, O.; Martin, G.J.; Abdelaziz, A. Botanical identification and ethno-medicinal uses of some underground part of medicinal plants collected and traded in Marrakech region. J. Med. Plants Res. 2013, 7, 2165-2169. [CrossRef]

55. Darias, V.; Martín-Herrera, D.; Abdala, S.; de la Fuente, D. Plants Used in Urinary Pathologies in the Canary Islands. Pharm. Biol. 2001, 39, 170-180. [CrossRef]

56. Raimondo, F.M.; Bazan, G. Una nuova associazione a palma nana della Sicilia sud-occidentale. In Proceedings of the 44th Congresso Società Italiana di Scienza della Vegetazione, Ravenna, Italy, 27-29 February 2008; p. 66.

57. López Darias, M.; Nogales, M. Effects of the invasive Barbary ground squirrel (Atlantoxerus getulus) on seed dispersal systems of insular xeric environments. J. Arid Environ. 2008, 72, 926-939. [CrossRef]

58. Padilla, D.P.; González-Castro, A.; Nogales, M. Significance and extent of secondary seed dispersal by predatory birds on oceanic islands: The case of the Canary archipelago. J. Ecol. 2012, 100, 416-427. [CrossRef]

59. Borgen, L. Chromosome numbers of vascular plants from the Canary Islands, with special reference to the occurrence of polyploidy. Nytt Mag. Bot. 1969, 16, 81-121.

60. Nogales, M.; González-Castro, A.; Marrero, P.; Bonnaud, E.; Traveset, A. Contrasting Selective Pressures on Seed Traits of Two Congeneric Species by Their Main Native Guilds of Dispersers on Islands. PLoS ONE 2013, 8, e63266. [CrossRef]

61. Biancardi, E.; Panella, L.W.; Lewellen, R.T. Beta Maritima: The Origin of Beets; Springer: New York, NY, USA, 2012.

62. Laface, V.L.A.; Musarella, C.M.; Cano Ortiz, A.; Quinto Canas, R.; Cannavò, S.; Spampinato, G. Three New Alien Taxa for Europe and a Chorological Update on the Alien Vascular Flora of Calabria (Southern Italy). Plants 2020, 9, 1181. [CrossRef] [PubMed]

63. Pinheiro de Carvalho, M.A.A.; Nóbrega, H.; Frese, L.; Freitas, G.; Abreu, U.; Costa, G.; Fontinha, S. Distribution and abundance of Beta patula Aiton and other crop wild relatives of cultivated beets on Madeira. J. Kult. 2010, 62, 357-366.

64. Frese, L.; Demeijer, E.; Letschert, J. New wild beetgenetic resources from Portugal and Spain. Zuckerindustrie 1990, 115, 950-955.

65. Kadereit, G.; Hohmann, S.; Kadereit, J.W. Asynopsis of Chenopodiaceae subfam. Betoideae and notes on the taxonomy of Beta. Willdenowia 2006, 36, 9-19. [CrossRef]

66. Leys, M.; Petit, E.J.; El-Bahloul, Y.; Liso, C.; Fournet, S.; Arnaud, J.F. Spatial genetic structure in Beta vulgaris subsp. maritima and Beta macrocarpa reveals the effect of contrasting mating system, influence of marine currents, and footprints of postglacial recolonization routes. Ecol. Evol. 2014, 4, 1828-1852. [CrossRef]

67. Castro, S.; Romeiras, M.M.; Castro, M.; Duarte, M.C.; Loureiro, J. Hidden diversity in wild Beta taxa from Portugal: Insights from genome size and ploidy level estimations using flow cytometry. Plant Sci. 2013, 207, 72-78. [CrossRef] [PubMed]

68. Pignatti, S. Flora d'Italia; Edagricole: Bologna, Italy, 1982.

69. Lange, W.; Debock, T.S.M. The diploidised meiosis of tetraploid Beta macrocarpa and its possible application in breeding sugar-beet. Plant Breed. 1989, 103, 196-206. [CrossRef]

70. Kishima, Y.; Mikami, T.; Hirai, A.; Sugiura, M.; Kinoshita, T. Beta chloroplast genomes: Analysis offraction I protein and chloroplast DNA variation. Theor. Appl. Genet. 1987, 73, 330-336. [CrossRef]

71. Bartsch, D.; Ellstrand, N.C. Genetic evidence for the origin of Californian wild beets (genus Beta). Theor. Appl. Genet. 1999, 99, 1120-1130. [CrossRef]

72. Ford-Lloyd, B. Beta adanensis. The IUCN Red List of Threatened Species 2011: E.T165230A5993528. 2011. Available online: https:/ / www.iucnredlist.org/species/165230/5993528 (accessed on 23 October 2020).

73. Duarte, M.C.; Draper Munt, D.; Branca, F.; Donnini, D.; Tavares, M. Beta macrocarpa. The IUCN Red List of Threatened Species 2011: E.T169911A6689398. 2011. Available online: https://www.iucnredlist.org/species/169911/6689398 (accessed on 23 October 2020).

74. Carvalho, M.; Frese, L.; Duarte, M.C.; Magos Brehm, J.; Tavares, M.; Santos Guerra, A.; Draper, D. Beta patula. The IUCN Red List of Threatened Species 2011: E.T162088A5532483. 2011. Available online: https:/ / www.iucnredlist.org/species/162088/5532483 (accessed on 23 October 2020).

75. Wagensommer, R.P.; Fröhlich, T.; Fröhlich, M. First record of the southeast European species Cerinthe retorta Sibth. \& Sm. (Boraginaceae) in Italy and considerations on its distribution and conservation status. Acta Bot. Gall. Bot. Lett. 2014, 161, 111-115. [CrossRef]

76. Hessini, K.; Jeddi, K.; El Shaer, H.M.; Smaoui, A.; Ben Salem, H.; Siddique, K.H.M. Potential of herbaceous vegetation as animal feed in semi-arid Mediterranean saline environments: The case for Tunisia. Agron. J. 2020, 112, 2445-2455. [CrossRef]

77. Mei, J.; Li, O.; Yang, X.; Qian, L.; Liu, L.; Yin, J.; Frauen, M.; Li, J.; Qian, W. Genomic relationships between wild and cultivated Brassica oleracea L. with emphasis on the origination of cultivated crops. Genet. Resour. Crop Evol. 2010, 57, 687-692. [CrossRef]

78. Stork, A.L.; Snogerup, S.; Wüest, J. Seed characters in Brassica section Brassica and some related groups. Candollea 1980, 35, 421-450. 
79. Snogerup, S.; Gustafsson, M.; von Bothmer, R. Brassica sect Brassica (Brassicaceae). I. Taxonomy and Variation. Willdenowia 1990, 19, 271-365.

80. Gómez-Campo, C. Collection, preservation and distribution of wild genetic resources. In Biology and Breeding of Crucifers; Gupta, S.K., Ed.; CRC Press: Boca Raton, FL, USA, 2009.

81. Snogerup, S.; Persson, D. Hybridization between Brassica insularis Moris and Brassica balearica Pers. Hereditas 1983, 99, 187-190. [CrossRef]

82. Hurtrez-Boussès, S. Genetic differentiation among natural populations of the rare Corsican endemic Brassica insularis Moris: Implications for conservation guidelines. Biol. Conserv. 1996, 76, 25-30. [CrossRef]

83. Maggioni, L.; Alessandrini, A. The occurrence of Brassica montana Pourr. (Brassicaceae) in the Italian regions of Emilia-Romagna and Marche, and in the Republic of San Marino. Ital. Bot. 2019, 7, 1-16. [CrossRef]

84. Biondi, E.; Gubellini, L.; Pinzi, M.; Casavecchia, S. The vascular flora of Conero Regional Nature Park (Marche, Central Italy). Flora Mediterr. 2012, 22, 67-167. [CrossRef]

85. Santo, A.; Mattana, E.; Frigau, L.; Marzo Pastor, A.; Picher Morelló, M.C.; Bacchetta, G. Effects of NaCl stress on seed germination and seedling development of Brassica insularis Moris (Brassicaceae). Plant Biol. 2017, 19, 368-376. [CrossRef] [PubMed]

86. Noël, F.; Maurice, S.; Mignot, A.; Glémin, S.; Carbonell, D.; Justy, F.; Guyot, I.; Olivieri, I.; Petit, C. Interaction of climate, demography and genetics: A ten-year study of Brassica insularis, a narrow endemic Mediterranean species. Conserv. Genet. 2010, 11, 509-526. [CrossRef]

87. Gustafsson, M.; Lannér-Herrera, C. Overview of the Brassica oleracea complex: Their distribution and ecological specificities. Bocconea 1997, 7, 27-37.

88. Mei, J.; Li, J.; Li, Q.; Yang, X.; Yin, J.; Cai, D.; Frauen, M.; Qian, W. Identification of Sclerotinia sclerotiorum resistance within Brassica oleracea. In Proceedings of the ISHS Brassica Symposium, 16th Crucifer Genetics Workshop, Lillehammer, Norway, 8-12 September 2008; p. 81.

89. Mithen, R.F.; Lewis, B.G.; Heaney, R.K.; Fenwick, G.R. Resistance of leaves of Brassica species to Leptosphaeria maculans. Trans. Br. Mycol. Soc. 1987, 88, 525-531. [CrossRef]

90. Mithen, R.F.; Magrath, R. Glucosinolates and resistance to Leptosphaeria maculans in wild and cultivated Brassica species. Plant Breed. 1992, 108, 60-68. [CrossRef]

91. Ramsey, A.D.; Ellis, P.R. Resistance in wild Brassicas to the cabbage whitefly, Aleyrodes proletella. Acta Hortic. 1996, 407, 507-514. [CrossRef]

92. Ellis, P.R.; Pink, D.A.C.; Barber, N.E.; Mead, A. Identification of high levels of resistance to cabbage root fly, Delia radicum, in wild Brassica species. Euphytica 1999, 110, 207-214. [CrossRef]

93. Horn, P.J.; Vaughan, J.G. Seed glucosinolates of fourteen wild Brassica species. Phytochemistry 1983, 22, 465-471. [CrossRef]

94. Velasco, L.; Becker, H.C. Variability for seed glucosinolates in a germplasm collection of the genus Brassica. Genet. Resour. Crop Evol. 2000, 47, 231-238. [CrossRef]

95. Warwick, S.I.; Francis, A.; Gugel, R.K. Guide to Wild Germplasm of Brassica and Allied Crops (Tribe Brassiceae, Brassicaceae), 3rd ed.; Part IV-Wild Crucifer Species as Sources of Agronomic Traits; 2009. Available online: http://www.brassica.info/info/publications/ guidewild/Guide_ed3_PART\%20IV_16July2009.pdf (accessed on 15 October 2020).

96. Pelgrom, K.T.B.; Broekgaarden, C.; Voorrips, R.E.; Bas, N.; Visser, R.G.F.; Vosman, B. Host plant resistance towards the cabbage whitefly in Brassica oleracea and its wild relatives. Euphythica 2015, 202, 297-306. [CrossRef]

97. Holsinger, K.E.; Gottlieb, L.D. Conservation of rare and endangered plants: Principles and prospects. In Genetics and Conservation of Rare Plants; Falk, D.A., Holsinger, K.E., Eds.; Oxford University Press: New York, NY, USA, 1991.

98. Hamrick, J.L.; Godt, M.J.W.; Murawski, D.A.; Loveless, M.D. Correlation between species traits andallozyme diversity: Implications for conservation biology. In Genetics and Conservation of Rare Plants; Falk, D.A., Holsinger, K.E., Eds.; Oxford University Press: New York, NY, USA, 1991.

99. Ruiz de la Torre, J. Conservation of Plant Species Within Their Native Ecosystems. In Plant Conservation in the Mediterranean; Gomez-Campo, C., Ed.; Junk Publishers: The Hague, The Netherlands, 1985; pp. 197-219.

100. Tito, G.A.; Chaves, L.H.G.; Fernandes, J.D.; Monteiro, D.R.; Vasconcelos, A.C.F.D. Effect of Copper, Zinc, Cadmium and Chromium in the Growth of Crambe. Agric. Sci. 2014, 5, 975-983. [CrossRef]

101. Tutus, A.; Comlekcioglu, N.; Karaman, S.; Alma, M.H. Chemical composition and fiber properties of Crambe orientalis and Crambe tataria. Int. J. Agric. Biol. 2010, 12, 286-290.

102. Comlekcioglu, N.; Karaman, S.; Ilcim, A. Oil composition and some morphological characters of Crambe orientalis var. orientalis and Crambe tataria var. tataria from Turkey. Nat. Prod. Res. 2008, 22, 525-532. [CrossRef]

103. Leppik, E.; White, G. Preliminary Assessment of Crambe germplasm resources. Euphytica 1975, 24, 681-689. [CrossRef]

104. Mcgregor, W.G.; Plessers, A.G.; Craig, B.M. Species trials with oil plants, I. Crambe. Can. J. Plant Sci. 1961, 41, 716-719. [CrossRef]

105. White, G.A.; Higgins, J.J. Culture of Crambe a new industrial oilseed crop. ARS, USDA. Prod. Res. Rep. 1966, 95, 1-20.

106. Bassegio, D.; Zanotto, M.D.; Santos, R.F.; Werncke, I.; Dias, P.P.; Olivo, M. Oilseed crop Crambe as a source of renewable energy in Brazil. Renew. Sust. Energ. Rev. 2016, 66, 311-321. [CrossRef]

107. Perrino, P. Risultati di una esplorazione e raccolta di Crambe (Crambe hispanica L.). In Proceedings of the 5th Simposio Nazionale Sulla Conservazione Della Natura, Bari, Italy, 22-27 April 1975; Volume I, pp. 283-292. 
108. Laghetti, G.; Piergiovanni, A.R.; Perrino, P. Yield and oil quality in selected lines of Crambe abyssinica Hochst. ex R.E. Fries and C. hispanica L. grown in Italy. Ind. Crops Prod. 1995, 4, 203-212. [CrossRef]

109. Perrino, P.; Laghetti, G.; Caliandro, A.; Marzi, V.; Galoppini, C.; Tomassini, C.; Porceddu, E.; Scarascia Mugnozza, G.T. Il Crambe (Crambe abyssinica Hochst. ex R.E. Fries): Una nuova e promettente oleifera industriale. Agric. Ric. 1992, 131, 41-50.

110. Liang, J.; Shu, J. Crambe L. In Flora of China; Wu, Z., Raven, P.H., Eds.; Science Press: Beijing, China, 2001; Volume 8, p. 26.

111. Kaplan, Z. Flora and phytogeography of the Czech Republic. Preslia 2012, 84, 505-573.

112. De Candolle, A.P. Crambe L. In Regni Vegetabilis Systema Naturale 2; Treuttel et Würtz: Paris, France, 1821.

113. Prina, A. Taxonomic review of the genus Crambe sect. Crambe (Brassicaceae, Brassiceae). An. Jard. Bot. Madr. 2009, 66, 7-24. [CrossRef]

114. Greuter, W.; Burdet, H.M.; Long, G. Med-Checklist 3; Conservatoire et Jardin Botaniques: Geneva Switzerland; Botanischer Garten \& Botanisches Museum: Berlin, Germany, 1986.

115. Yildiztugay, E.; Küçüködük, M.; Özel, M.; ÖZDEMIR, C. A New Record for the Flora of Turkey: Crambe hispanica L. (Brassicaceae). Turk. J. Bot. 2009, 33, 227-230.

116. Marhold, K. Brassicaceae. Euro+Med Plantbase-The Information Resource for Euro-356. 2011. Available online: http://ww2 .bgbm.org/EuroPlusMed / query.asp (accessed on 21 October 2020).

117. Piovan, A.; Cassina, G.; Filippini, R. Crambe tataria: Actions for ex situ conservation. Biodivers. Conserv. 2011, $20,359-371$. [CrossRef]

118. Perrino, E.V.; Tomaselli, V.; Signorile, G.; Angiulli, F.; Silletti, G. Vegetation with Crambe hispanica L. in Apulia Region (Vegetazione a Crambe hispanica L. in Puglia). Fitosociologia 2011, 48, 99-107.

119. Cristaudo, A.; Margani, I. Specie nuove ed interessanti per la Flora Siciliana. Inform. Bot. Ital. 2005, 37, $1153-1159$.

120. Scelsi, F.; Spampinato, G. Segnalazione di nuovi reperti per la flora dell'Aspromonte (Italia meridionale). Giorn. Bota. Ital. 1994, 128, 384. [CrossRef]

121. Perrino, E.V.; Tomaselli, V.; Perrino, P. Conservation in Situ and ex Situ of Crambe hispanica L. (Gargano Mountain, Apulia). Ital. J. Agron. 2009, 4, 431-436.

122. Chiapella Feoli, L.; Poldini, L. Prati e pascoli del Friuli (NE Italia) su substrati basici. Stud. Geobot. 1995, $13,3-140$.

123. Löve, A. IOPB Chromosome Number Reports LXI. Taxon 1978, 27, 375-392. [CrossRef]

124. Kupriianov, A.N.; Turalin, B.A.; Kurbatova, N.V.; Kurmanbaeva, M.S.; Abidkulova, K.T.; Bazargalieva, A.A. Features of age-related conditions of the Crambe tataria Sebeók in Western Kazakhstan. EurAsian J. Biosci. 2020, 14, 177-182.

125. Oroian, S.; Sămăghiţan, M.; Tănase, C. Plants species of community interest identified in the flora of the Transylvanian plain (Mureş County). Stud. Univ. Vasile Goldiş Ser. Ştiinţele Vieţii 2017, 27, 209-214.

126. Demina, O.; Bragina, T. Fundamental basis for the conservation of biodiversity of the Black Sea-Kazakh Steppes. Hacquetia 2014, 13, 215-228. [CrossRef]

127. Rivera, D.; Matilla, G.; Obón, C.; Alcaraz, F. Plants and Humans in the Near East and the Caucasus: Ancient and Traditional Uses of Plants as Food and Medicine: An Ethnobotanical Diachronic Review; Ediciones de la Universidad de Murcia: Murcia, Spain, 2012; Volume 2.

128. Von Raab-Straube, E. Convolvulaceae. Euro+Med Plantbase-The Information Resource for Euro-Mediterranean Plant DiverSity. 2018. Available online: http:/ /ww2.bgbm.org/EuroPlusMed/ (accessed on 10 November 2020).

129. Austin, D.F. Salt Marsh Morning-glory (Ipomoea sagittata, Convolvulaceae)—An Amphi-Atlantic Species. Econ. Bot. 2014, 68, 203-219. [CrossRef]

130. Wood, J.R.I.; Muñoz-Rodríguez, P.; Williams, B.R.M.; Scotland, R.W. A foundation monograph of Ipomoea in the New World. PhytoKeys 2020, 143, 1-823. [CrossRef]

131. Silvestre, S. Ipomoea L. In Flora Iberica; Castroviejo, S., Aedo, C., Laínz, M., Muñoz Garmendia, F., Nieto Feliner, G., Paiva, J., Benedí, C., Eds.; Real Jardín Botánico, CSIC: Madrid, Spain, 2012; Volume 11, pp. 279-286.

132. Bartolucci, F.; Domina, G.; Alessandrini, A.; Angiolini, C.; Ardenghi, N.M.G.; Bacchetta, G.; Banfi, E.; Bolpagni, R.; Bonari, G.; Bräuchler, C.; et al. Notulae to the Italian native vascular flora: 7. Ital. Bot. 2019, 7, 125-148. [CrossRef]

133. Galasso, G.; Conti, F.; Peruzzi, L.; Ardenghi, N.M.G.; Banfi, E.; Celesti-Grapow, L.; Albano, A.; Alessandrini, A.; Bacchetta, G.; Ballelli, S.; et al. An updated checklist of the vascular flora alien to Italy. Plant Biosyst. 2018, 152, 556-592. [CrossRef]

134. Medagli, P.; Bianco, P.; D’Emerico, S.; Ruggiero, L.; Gennaio, R.; Scarpina, L. Nuove stazioni e distribuzione in Italia di Ipomoea sagittata Poiret (Fam. Convolvulaceae). Thalass. Salent. 1994, 20, 17-19.

135. Medagli, P. La Riserva Naturale delle Cesine in Provincia di Lecce. Osservazioni sull'ambiente vegetale. Quad. Cent. Stud. Geot. Ing. 1981, 3, 5-16.

136. Bianco, P.; Gabrieli Tommasi, I.; Medagli, P. Nuove stazioni pugliesi e scheda palinologica di Ipomoea sagittata Poiret, entità anfiatlantica subtropicale. Inform. Bot. Ital. 1986, 18, 85-93.

137. Géhu, J.M.; Biondi, E. Données sur la vegetation des ceintures d'atterrissement des Lacs Alimini (Salento, Italie). Doc. Phytosoc. 1988, 11, 353-378.

138. Domina, G.; Ciccarello, S.; Scafidi, F. Sesbania punicea (Cav.) Benth. (Fabaceae). Notulae alla flora esotica d'Italia 12 (244). Inform. Bot. Ital. 2015, 47, 77.

139. Brullo, S.; Scelsi, F.; Siracusa, G. Contributo alla conoscenza della vegetazione terofitica della Sicilia occidentale. Boll. Acc. Gioenia Sci. Nat. 1994, 27, 341-365. 
140. Pasta, S.; La Mantia, T. Lineamenti della flora e della vegetazione dell'area della Riserva Naturale "Grotta di Santa Ninfa". Nat. Sicil. 2001, 25, 271-297.

141. Troia, A.; Napolitano, T. Segnalazioni floristiche e vegetazionali per le zone umide costiere del territorio di Petrosino (Sicilia occidentale). Nat. Sicil. 2017, 41, 25-34.

142. Maiorca, G.; Spampinato, G.; Caprio, A. Flora e vegetazione dei laghi costieri La Vota (Calabria centro-occidentale). Fitosociologia 2002, 39, 81-108.

143. Cervini, M.; Tramonti, P. Studio di Fattibilita' per la Pianificazione Territoriale e la Gestione dei Monumenti Naturali del Parco Regionale dei Monti Ausoni e Lago di Fondi e per il Programma Pluriennale di Promozione Economica e Sociale. 2009. Available online: http:/ / www.cervini.it/bbb / file_content/fl19.pdf (accessed on 20 November 2020).

144. Preet, R.; Gupta, R.C. Meiotic studies of the Convolvulaceae Juss. from Indian Hot Desert. Chromosome Bot. $2018,12,77-85$.

145. Tomaselli, V.; Di Pietro, R.; Sciandrello, S. Plant communities structure and composition in three coastal wetlands in southern Apulia (Italy). Biologia 2011, 66/6, 1027-1043. [CrossRef]

146. Biondi, E.; Casavecchia, S.; Guerra, V. Analysis of vegetation diversity in relation to the geomorphological characteristics in the Salento coasts (Apulia-Italy). Fitosociologia 2006, 43, 25-38.

147. Troia, A.; Adragna, F.; Campisi, P.; Campo, G.; Dia, M.; Ilardi, V.; La Mantia, T.; La Rosa, A.; Lo Valvo, M.; Muscarella, C.; et al. I pantani di Anguillara (Calatafimi Segesta, Trapani): Dati preliminari sulla biodiversità a supporto della tutela del biotopo. Nat. Sicil. 2016, 40, 171-200.

148. Roberts, R.A. Sweetpotato weevil . In Insects, the Yearbook of Agriculture; Stefferud, A., Ed.; U.S. Department of Agriculture: Washington, DC, USA, 1952; pp. 527-553.

149. Kearney, J.; Smartt, J. The grasspea Lathyrus sativus (Leguminosae-Papilionoideae). In Evolution of Crop Plants; Simmonds, N.W., Ed.; Longman: New York, NY, USA, 1976.

150. Yunus, A.G.; Jackson, M.T. The gene pools of the grasspea (Lathyrus sativus L.). Plant Breed. 1991, 106, 319-328. [CrossRef]

151. Heywood, V.; Casas, A.; Ford-Lloyd, B.; Kell, S.; Maxted, N. Conservation and sustainable use of crop wild relatives. Agric. Ecosyst. Environ. 2007, 121, 245-255. [CrossRef]

152. Vaz Patto, M.C.; Rubiales, D. Lathyrus diversity: Available resources with relevance to crop improvement-L. sativus and L. cicera as case studies. Ann. Bot. 2014, 113, 895-908. [CrossRef]

153. Khawaja, H.I.T.; Ellis, J.R.; Sybenga, J. Cytogenetics of Lathyrus palustris, a natural autohexaploid. Genome 1995, 38, 827-831. [CrossRef]

154. Ali, H.B.M.; Osman, S.A. Ribosomal DNA localization on Lathyrus species chromosomes by FISH. J. Genet. Eng. Biotechnol. 2020, 18, 63. [CrossRef] [PubMed]

155. Roskov, Y.; Zarucchi, J.; Novoselova, M.; Bisby, F. ILDIS: World Database of Legumes (version 12, May 2014). In Species 2000 and ITIS Catalogue of Life; Roskov, Y., Ower, G., Orrell, T., Nicolson, D., Bailly, N., Kirk, P.M., Bourgoin, T., DeWalt, R.E., Decock, W., van Nieukerken, E., Eds.; Naturalis: Leiden, The Netherlands, 2020; Available online: http:/ /www.catalogueoflife.org/col. (accessed on 15 November 2020).

156. Lucchese, F.; Lattanzi, E. Una specie nuova per l'Italia peninsulare: Lathyrus amphicarpos L. (=L. quadrimarginalus Bory et Chaub.) nel Lazio. Arch. Bot. Ital. 1988, 64, 93-101.

157. Anzalone, B.; Iberite, M.; Lattanzi, E. La Flora vascolare del Lazio. Inform. Bot. Ital. 2010, 42, 187-317.

158. Caldarella, O.; Gianguzzi, L.; Romano, S.; Fici, S. The vascular flora of Nature Reserve “Pizzo Cane, Pizzo Trigna and Grotta Mazzamuto" (NW Sicily). Webbia 2009, 64, 101-151. [CrossRef]

159. Gianguzzi, L.; Geraci, A.; Certa, G. Note corologiche ed ecologiche su taxa indigeni ed esotici della flora vascolare Siciliana. Nat. Sicil. 1995, 4, 39-62.

160. Wagensommer, R.P.; Marrese, M.; Perrino, E.V.; Bartolucci, F.; Cancellieri, L.; Carruggio, F.; Conti, F.; Di Pietro, R.; Fortini, P.; Galasso, G.; et al. Contributo alla conoscenza floristica della Puglia: Resoconto dell'escursione del Gruppo di Floristica (S.B.I.) nel 2011 nel settore meridionale dei Monti della Daunia. Inform. Bot. Ital. 2014, 46, 175-208.

161. Pastor-Cavada, E.; Juan, R.; Pastor, J.E.; Alaiz, M.; Vioque, J. Antioxidant activity of seed polyphenols in fifteen wild Lathyrus species from South Spain. LWT 2009, 42, 705-709. [CrossRef]

162. Pastor-Cavada, E.; Pastor, J.E.; Juan, R.; Vioque, J. Nutritional Characterization of Wild Legumes (Lathyrus and Vicia Genera); Satou, H., Nakamura, R., Eds.; Chapter 2; Legumes-Type Nutritional Composition and Health Benefitss; Nova Science Publishers: New York, NY, USA, 2013; pp. 41-92.

163. Zoric, L.; Merkulov, L.; Lukovik, J.; Boza, P.; Krstic, B. Evaluation of forage quality of Lathyrus L. species based on histological characteristics. Acta Agron. Hung. 2011, 59, 47-55. [CrossRef]

164. Przybylska, J.; Zimniak-Przybylska, Z.; Krajewski, P. Diversity of seed albumins in some Lathyrus species related to L. sativus L.: An electrophoretic study. Genet. Resour. Crop Evol. 1999, 46, 261-266. [CrossRef]

165. Lasen, C. Descrizione degli Habitat dell'Alto Adige; Provincia Autonoma di Bolzano-Alto Adige, Ripartizione Natura, Paesaggio e Sviluppo del Territorio: Bolzano, Italy, 2017.

166. Angelini, P.; Bianco, P.; Cardillo, A.; Francescato, C.; Oriolo, G. Gli Habitat in Carta della Natura: Schede Descrittive degli Habitat per la Cartografia alla Scala 1:50.000; ISPRA, SystemCart S.r.l.: Roma, Italy, 2009; p. 335. 
167. Perrino, E.V.; Magazzini, P.; Musarella, C. Management of grazing "buffalo" to preserve habitats by Directive $92 / 43$ EEC in a wetland protected area of the Mediterranean coast: Palude Frattarolo, Apulia, Italy. Euro Mediterr. J. Environ. Integr. 2020. accepted. [CrossRef]

168. Caputo, G. Significato dei rapporti tra Vicia serinica Uechtr. et Huter e Vicia argentea Lupeyr. Delpinoa 1967, 9, 65-74.

169. Foggi, B.; Ricceri, C. Vicia cusnae Foggi et Ricceri, sp. nov. (Leguminosae) nell'Appennino settentrionale. Webbia 1989, 43, 25-31. [CrossRef]

170. Davis, P.H. Flora of Turkey and the East Aegean Islands 3; Edinburgh University Press: Edinburgh, UK, 1970.

171. Alessandrini, A.; Branchetti, G. Flora Reggiana; Cierre Edizioni: Verona, Italy, 1997.

172. Greuter, W.; Burdet, H.M.; Long, G. Med-Checklist 4; Conservatoire et Jardin Botanique: Geneva, Switzerland; Botanischer Garten \& Botanisches Museum: Berlin, Germany, 1989.

173. Gustavsson, L.A. Floristic reports from the high mountains of Sterea Ellas, Greece, 1. Bot. Not. 1978, 131, 7-25.

174. Strid, A.; Papanicolaou, K. Floristic notes from the mountains of Northern Greece. Materials for the Mountain Flora of Greece, 7. Nord. J. Bot. 1981, 1, 66-82. [CrossRef]

175. Caputo, G. Vicia serinica Uechtr et Huter, endemica orofila del massiccio del Sirino (Appennino Lucano). Cenni storici, ecologia e cariologia. Delpinoa 1966-1967, 8-9, 37-56.

176. Tomaselli, V.; Cimmarusti, G.; Forte, L.; Perrino, P. Caratterizzazione ecologica e fitosociologica dei popolamenti a Vicia serinica Uechtr et Huter del Massiccio del Sirino-Papa (Basilicata-Pz). In Proceedings of the 42th Congress “Le foreste d'Italia: Dalla Conoscenza alla Gestione", Potenza and Matera, Italy, 20-23 June 2006; pp. 69-70.

177. Favarger, C.; Contandriopoulos, J. Essai sur l'endemisme. Bull. Soc. Bot. Suisse 1961, 71, 384-408.

178. Van Rheede Van Oudshoorn, K.; Van Rooyen, M.W. Dispersal Biology of Desert Plants: Adaptations of Desert Organism; Springer: Berlin, Germany, 1999.

179. Olivier, L.; Galland, J.P.; Maurin, H. Livre Rouge de la Flore Menacée de France; Collection Patrimoines Naturels No. 20; Museo National d'Histoire Naturelle, Conservatoire Botanique National du Porquerolles, Ministère de l'Environnement: Paris, France, 1995.

180. Flynn, S.; Turner, R.M.; Stuppy, W.H. Seed Information Database. 2006. Available online: http://data.kew.org/sid/ (accessed on 21 November 2020). 